\title{
FEARGUS O'CONNOR AND THE NORTHERN STAR*
}

The first edition of the Northern Star and Leeds General Advertiser was published on November 18th, 1837, with Feargus O'Connor as proprietor, Joshua Hobson as printer and publisher, and the Rev. William Hill as editor. Its price was $4 \frac{1}{2} \mathrm{~d} .{ }^{1}$ Together with the platform the Northern Star provided the essential medium of national communication and organization for the Chartist movement. The Star was the most important agency for the integration and transformation of disparate local radical agitation and organization into the national Chartist movement. Throughout the Chartist period the Star gave local working-class protest a national focus. It brought national perspective to the localities and gave local radicalism national coverage. $^{2}$

For O'Connor the establishment of the Star marked the all-important convergence of the powers of the press with those of the platform. Already acclaimed Hunt's successor, Feargus now assumed the mantle of William Cobbett. He understood the crucial interdependence between the platform and the press. ${ }^{3}$ Early in his career O'Connor had

\footnotetext{
* I am indebted to Mrs Dorothy Thompson for her advice, encouragement and the many references which she has passed on from her own research, and to $\mathrm{Mr}$ Edward Thompson and Dr Ann Epstein for having read and commented on an earlier draft of this article.

1 Only a fragment exists of the first edition of the Northern Star, in the Place Newspaper Collection, Set 56 (1836 - June 1838), f. 155, British Museum. Of the first seven editions only Nos 3 and 5, December 2 and 16, 1837, have been located, in the files of the Public Record Office, HO 73/52.

${ }^{2}$ A. R. Schoyen, The Chartist Challenge (London, 1958), p. 34, comments: "In its columns [...] isolated incidents gained an added significance as part of a larger whole, and working-class Radicals scattered about the country could see themselves for the first time as part of a great movement of men with like ideas."

'See H. Jephson, The Platform, Its Rise and Progress (London, 1892), II, pp. 603-04, for a discussion of the relationship of the platform to the press.
} 
noted the significance of a free press to national agitation and to any attempt to address simultaneously a local and national audience. ${ }^{1}$ By early 1837 he was unable to depend upon press coverage commensurate with his continual radical touring. In reply to a request for a report of his latest Northern tour from Bronterre O'Brien's short-lived National Reformer, O'Connor noted: "the fact of being obliged to apply to me, is a very severe sarcasm upon the press, because, if I had been a beardless Tory, or a doating old Whig, every particular of my downlying and up-rising, would have been a matter of importance: but as I represented feelings, which the united tyranny of both cannot suppress, silence became necessary."2 The Star became the means through which O'Connor broke that silence. He told a rally at Carlisle in July 1838:

"The severity of the press has made such demonstrations as the present necessary, and when I discovered this fact, I armed myself with its power, and today I have not come alone. I was not fool enough to leave my address and your response in the hands of either Whig or Tory, so I have brought a reporter at my own expense, and your meeting shall go to the world through the medium of the Northern Star."3

Probably no circumstance was more important to Feargus O'Connor's eventual establishment of an unrivalled Chartist leadership than his ownership of the movement's newspaper. ${ }^{4}$

The Star was the direct heir to a tradition of popular democracy pioneered in the pages of the radical unstamped press. ${ }^{5}$ In an address

1 For instance, see Cleave's Weekly Police Gazette, December 26, 1835, p. 3; Weekly True Sun, January 3,1836, p. 982. From his earliest days on the Irish platform, O'Connor saw the importance of the presence of the press. William J. O'Neill Daunt, Eighty-Five Years of Irish Histcry, 1800-1885 (London, 1886), I, pp. 232, 236-37.

2 Bronterre's National Reformer, January 28, 1837, p. 29. Feargus recalled in 1841: "In 1837, I visited Yorkshire and the North again; but the first blush of curiosity having faded, I found that the press was entirely mute, while I was working myself to death, and that a meeting in one town did nothing for another." Northern Star, January 16, 1841, p. 7.

3 Northern Star, July 21, 1838, p. 3.

4 W. E. Adams, Memoirs of a Social Atom (London, 1903), I, p. 204, noted:

"The ascendency of Feargus O'Connor would have been unaccountable but for the fact that he owned the Northern Star. [...] It was almost the only paper that the Chartists read".

5 For the unstamped press, see C. D. Collet, History of the Taxes on Knowledge (2 vols; London, 1899); W. H. Wickwar, The Struggle for the Freedom of the Press (London, 1928) ; P. Hollis, The Pauper Press (Oxford, 1970); J. H. Wiener, The War of the Unstamped (Ithaca, N.Y., 1969). 
"To the Radicals of England", published in 1836, O'Connor had declared: "The unstamped Press was the guardian of the unrepresented; the unstamped Press depended for support upon the integrity of its principles - it could not live at variance with public opinion." 1 Through his defence of the editors of the radical True Sun while an MP for County Cork, and most significantly through his leadership of the Metropolitan Radical Associations during the final stages of the struggle of the unstamped press, O'Connor had already demonstrated his concern for the creation of a free and radical working-class press. ${ }^{2}$ The "pauper press" had been extinguished by the Whig Government's reduction of the newspaper stamp in 1836. Hetherington sounded its death knell in the first edition of his stamped London Dispatch: "Against a power like this, personal courage is useless [...] unless [...] some means can be devised either to print newspapers without types and presses, or render the premises [...] inaccessible to armed force, no unstamped paper can be attempted with success."3

Thus the Star was a stamped newspaper. While fully exploiting the advantages which the stamp conferred - principally free postal delivery and the legal publication of news - the Star incorporated the ideology and much of the spirit and personnel of the unstamped, along with a readership which the unstamped press had helped to educate. The remaining penny stamp was a symbol which divided the middle and working classes. ${ }^{4}$ The Star succinctly summed up the situation: "The reduction upon the stamps has made the rich man's paper cheaper, and the poor man's paper dearer." In his introductory address to the readers of the Star, O'Connor immediately drew their attention to the paper's stamp.

"Reader - Behold that little red spot, in the corner of my newspaper. That is the Stamp; the Whig beauty spot; your plague spot.

1 True Sun, April 22, 1836, p. 4.

2 For O'Connor's defence of the True Sun, see Parliamentary Debates, Third Series, XXV (1834), cc. 400-03; Weekly True Sun, June 22, 1834, pp. 338 , 341-43; July 6, pp. 354, 356; July 27, pp. 377-78. For O'Connor and the unstamped in general, see True Sun; Weekly True Sun; Cleave's Weekly Police Gazette, 1835-36; Poor Man's Guardian, late 1835; Radical, 1836; Twopenny Dispatch, 1836; Wiener, op. cit., pp. 254-57.

${ }^{3}$ London Dispatch, September 17, 1836, p. 1.

4 Speaking in favour of total repeal in 1836, O'Connor had claimed "that the great object of the Whigs had been to separate the middle and working classes; and that a penny stamp would go to secure this object. The middle classes would have cheaper newspapers than they hitherto had, but the working classes would have no papers at all." Cleave's Weekly Police Gazette, April 23, 1836, p. 4.

5 Northern Star, June 2, 1838, p. 1. 
Look at it: I am entitled to it upon the performance of certain conditions: I was ready to comply, and yet, will you believe, that the little spot you see has cost me nearly Eighty Pounds in money, together with much anxiety, and nearly one thousand miles of night and day travelling $[\ldots]$ but for the present suffice to say, - there it is, - it is my license to teach."1

Thus from the outset $O^{\prime}$ Connor placed both his paper and himself within the context of a rich tradition of radical consciousness concerned with the working class's acquisition and control of their own channels of learning and communication.

Historians of the Chartist movement have offered a less generous view of both O'Connor and his paper, criticizing the manner in which the Star was established and O'Connor's subsequent control. For instance, Mark Hovell concluded that O'Connor "contributed little or nothing" in the way of finance for the Star; as a source of graft he compared it to "Tammany Hall in embryo"; and for quality readily accepted Francis Place's opinion that the paper degraded the entire radical press. ${ }^{2}$ More recently it has been claimed that not only was $\mathrm{O}^{\prime}$ Connor's control narrow and undemocratic and his financial contribution negligible, but that he also perverted the paper's original platform and even plundered the idea of starting a journal. ${ }^{3}$ Despite such widely held views there is evidence to support a more sympathetic picture of $\mathrm{O}^{\prime}$ Connor in the role of newspaper proprietor, a picture which also helps to support an impression of a more democratic relationship between O'Connor and the Chartist rank and file. It is hoped that this article will be seen within the larger context of a necessary re-evaluation of the nature of Chartism, which must involve the study of the cultural and organizational aspects of the movement; which emphasizes the intelligence and independence of rank-and-file Chartist support; and which offers a re-examination of Chartism's national leadership and especially the leadership of Feargus O'Connor. ${ }^{4}$

1 Ibid., November 18,1837, p. 1.

2 M. Hovell, The Chartist Movement, ed. and completed by T. F. Tout, 2nd ed. (Manchester, 1925), p. 96; Place in British Museum, Add. Mss 27820, f. 154. Hovell's view of the question of the Star's establishment and financing was taken from W. Lovett, Life and Struggles of William Lovett (London, 1967 ed., p. 143, note), which in turn was based on Robert Lowery's autobiography, published in The Weekly Record of the Temperance Movement, October 11, 1856, p. 235.

${ }^{3}$ E. Glasgow, "The Establishment of the Northern Star Newspaper", in: History, XXXIX (1954), pp. 54-67. This view is incorporated in D. Read and E. Glasgow, Feargus O'Connor: Irishman and Chartist (London, 1961), pp. 56-65.

- On the question of the need for a serious re-evaluation of O'Connor's leadership, see Professor J. Saville's introduction to R. G. Gammage, History of the Chartist 
O'Connor first broached the subject of establishing a radical paper in the North to Joshua Hobson, the radical printer of Leeds and veteran of the unstamped, at an anti-Poor-Law meeting on Hartshead Moor, in May 1837. ${ }^{1}$ Hobson told Feargus that he thought the idea a good one and that Leeds would be an excellent place for such a venture. A few days later, O'Connor visited Hobson in Leeds to outline his plans for such a paper, and to formally propose that Hobson be publisher and printer. However, O'Connor was staggered when Hobson told him that no provincial printer had the machinery required to produce the kind of paper intended, nor would any risk the initial outlay necessary on a paper which might quickly fail. O'Connor had therefore to decide whether to abandon the idea and have the paper printed in London, or to produce the funds needed to launch such an expensive project in the North. Within a few weeks he returned to Leeds to inform Hobson that he was determined to proceed with the plan as conceived, and asked Hobson to suggest an editor. Hobson named the Rev. William Hill, the radical Swedenborgian minister at Hull, who was eventually hired. O'Connor set Hobson to order the type and other equipment, and undertook to purchase a printing press himself in London. Throughout these negotiations O'Connor had given the impression of a gentleman who could afford to sustain the capital costs involved. Hobson related that he knew O'Connor, "only by public repute", as a former radical Member of Parliament, an agitator in the people's cause and a "gentleman". Therefore, with reason, Hobson assumed he was a man of some wealth.

Only after the scheme was well off the ground, the print having been delivered and the press under construction in London, did $\mathrm{O}^{\prime}$ Connor suggest his plan for raising $£ 800$ in one-pound shares on his own security with a fixed dividend of $20 \%$. O'Connor maintained that this would involve other radicals, whose interest would help ensure the paper's initial success. For his own part, besides guaranteeing the fixed interest on shares, $\mathrm{O}^{\prime}$ Connor was to give another $£ 400$ from his own resources. ${ }^{2}$ Lawrence Pitkeithley persuaded O'Connor to lower

Movement, reprint of 2nd ed. (London, 1969); also my review of J. T. Ward, Chartism (London, 1973), in Bulletin of the Society for the Study of Labour History, No 28 (1974), pp. 70-71.

1 The following account is based largely on the letters which Joshua Hobson wrote to the Manchester Examiner, November-December 1847, and primarily on the letter of November 6 . This also formed the basis for the account given by $\mathrm{E}$. Glasgow in his article, loc. cit.

2 Northern Star, March 10, 1838, p. 8; January 18, 1845, p. 4; F. O'Connor, Reply to John Watkins's Charges (London, 1843), p. 16. 
the interest rate to a more modest $10 \%$, and the campaign was opened at Hull. Here Hill was able to transfer funds raised for an earlier newspaper project of his own to the cause of the Star, "which seemed to answer the shareholders' purpose better than their own [scheme]". ${ }^{1}$ John Ardill, the Star's clerk and bookkeeper, was able to secure funds in Leeds and Halifax. In Bradford Peter Bussey helped raise funds, and Pitkeithley stirred up Huddersfield. O'Connor campaigned throughout the West Riding and South Lancashire with his usual zeal in the cause of the new journal. ${ }^{2}$ Eventually $£ 690$ was raised, of which about $£ 500$ came from Leeds, Halifax, Hull, Bradford and Huddersfield. Money was also raised at Oldham, Rochdale, Keighley and Barnsley. ${ }^{3}$ From Ashton-under-Lyne the Rev. J. R. Stephens contributed $£ 20 .{ }^{4}$ The first edition of the Star "saw the light, amidst difficulties and hair-breath escapes 'too numerous to mention"'. ${ }^{5}$ Feargus was rushing between the North and London - raising funds to pay the men, procuring stamps, paying off creditors, and also attending the trial of the Glasgow cotton spinners. ${ }^{6}$ Even Francis Place gave O'Connor credit for having been "one of the most active indefatigable men in existence". ${ }^{7}$ With constant work and little sleep the Star's first edition of three thousand copies was published. "The first week we could have sold three times three thousand, but we had not stamps to print more", wrote Hobson, which says something for the pre-publication publicity of O'Connor and local radical leaders. Within four weeks the Star was a profitable concern, and within little over a year it was the most widely circulated provincial paper in the land. ${ }^{8}$

O'Connor's contribution to the establishment of the Star has been both undervalued and seriously misunderstood. A major criticism has been that, while providing no financial support for the Star, O'Connor

1 Manchester Examiner, November 6, 1847.

2 Ibid. For example, O'Connor was in Oldham in September 1837, speaking on the principles on which he intended to conduct a new paper called the Northern Star. Several weeks later he was in Rochdale, where only thirty shares had so far been taken up. Manchester and Salford Advertiser, September 23, 1837, p. 3; October 7, p. 3; Butterworth manuscript diary, Oldham Public Library, September 16, 1837. O'Connor was continually agitating in South Lancashire and the West Riding in autumn-winter 1837, see Leeds Times, August 5 December 16, 1837.

${ }^{3}$ Northern Star, January 18, 1845, p. 4; O'Connor, Reply, op. cit., p. 16.

4 G. J. Holyoake, Life of Joseph Rayner Stephens (London, 1881), p. 181.

3 Manchester Examiner, November 6, 1847.

6 Northern Star, January 16, 1841, p. 7; Manchester Examiner, November 6, 1847.

7 British Museum, Add. Mss 27820, f. 13.

8 Manchester Examiner, November 6, 1847. 
manipulated the people's funds to his own egotistical designs. Dr Glasgow in his article on the establishment of the Star concluded that "it may safely be said that in fact he [O'Connor] added nothing, at any rate to begin with", to the Star's funds. This conclusion is based on a handful of hostile sources, of which Hobson's 1847 account is by far the most important. ${ }^{1}$ Most probably, O'Connor found costs for such an ambitious venture higher than anticipated, and saw the share scheme as a quick way to raise funds and involve leading local radicals. The share scheme was proposed only after the establishment of the paper was well under way. Also O'Connor was to contribute a further $£ 400$ himself.

Almost certainly $£ 690$ was not enough to launch a paper like the Star. By 1837 Hetherington's London Dispatch press was worth $£ 1500$

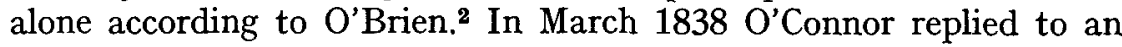
attack in the London Dispatch (no longer owned by Hetherington): "I have expended considerably more than $£ 1,000$ " on the Star. ${ }^{3}$ In 1841 O'Connor pointed out that the working class had put up only $£ 670$, "to which I have put several thousands"; in 1843 he claimed $£ 2000$ represented the initial outlay on the Star, and in 1845 that the machinery for producing the paper had alone cost $£ 2340 .{ }^{4}$ As for his ability to have made a contribution to the lauching of the paper, O'Connor wrote in 1847: "I sold one estate alone for $£ 3,600$. I sold $£ 1,000$ worth of timber but did not cut it down. I received a mortgage for $£ 5,000 " .5$ Certainly he could have made a substantial contribution.

1 Glasgow, loc. cit., p. 64. Dr Glasgow only seems to consider the evidence of Hobson and Alexander Somerville in the Manchester Examiner, OctoberNovember 1847, Robert Lowery in his autobiography, loc. cit., and John Watkins in his Impeachment of Feargus O'Connor (London, 1843). Of these hostile sources only Hobson had first-hand knowledge concerning the Star's establishment. Although Hobson's account appears to be accurate, it should be noted that his articles were written in the context of a bitter financial dispute between himself and O'Connor.

${ }^{2}$ London Mercury, June 4, 1837, p. 297, cited by P. Hollis, The Pauper Press, op. cit., p. 135. It was more expensive to start a provincial paper than a London paper. Because of the large number of printers in London it was possible to arrange a trial run for a new paper. This was usually impossible in the provinces. Thus a large initial capital outlay was necessary to start a provincial paper, without the benefit of a trial run. D. Read, Press and People, 1790-1850 (London, 1961). p. 80.

${ }^{3}$ Northern Star, March 10, 1838, p. 8; London Dispatch, March 11, 1838, p. 620 ; March 18, p. 628.

4 Northern Star, April 24, 1841, p. 7 ; January 18, 1845, p. 4, in reply to a letter in Lloyds Weekly London Newspaper, January 12, 1845 p. 5, from "An Independent Chartist” (John Watkins); O'Connor, Reply, op. cit., p. 16.

${ }^{5}$ O'Connor, Reply of Feargus O'Connor to the Charges against His Land and Labour Scheme (Manchester, 1847), p. 10. According to Wheeler, O'Connor sold 
By the autumn of 1837 he had already sustained the cost of two contested Irish elections, one of which was controverted, one English election, two years in Parliament and two years of extensive independent agitation. ${ }^{1}$ In 1835 O'Connor had an annual income - quite apart from his profession as a barrister - of $£ 750$, as well as considerable assets in Ireland. ${ }^{2}$ Although O'Connor may well have exaggerated his initial outlay on the Star, there seems little reason to doubt that he invested a considerable sum in its establishment, and no reason to believe that he had no capital to advance.

Controversy over financial matters was endemic to a movement as large and often divided as the Chartist movement. Similar accusations of misappropriation of the people's funds were made about O'Connor's handling of the National Land Company. In this instance a Parliamentary committee found that the Company owed O'Connor several thousand pounds. ${ }^{3}$ The question of financing of the Chartist agitation raises broader issues concerning the nature of Chartist organization and leadership. The legitimacy of O'Connor's own leadership depended upon his ability to maintain his position as an independent gentleman of the platform and on his often repeated boast that "I never would travel a mile at your expense, or accept a farthing for any poor service which I may be able to render your cause". ${ }^{4}$ The importance of the claims and counter-claims concerning $O^{\prime}$ Connor and the financing of the "people's paper" can only be understood within this context.

Whatever O'Connor's direct financial contribution to the Star, his importance to its successful establishment is beyond doubt. It is apparent that the money raised through shares was extended on the basis of O'Connor's own financial security and high-standing within the ranks of the Northern radicals. Nor was it the shareholders alone who stood to lose had the Star collapsed. Besides being responsible for the fixed interest on the shares, O'Connor was also responsible as proprietor for many of the initial costs and debts incurred, which went well beyond the sums advanced by shareholders. Even more important,

Fort Robert, his Irish home, in 1841 to keep the Star going. T. M. Wheeler, A Brief Memoir of the Late Feargus O'Connor (London, 1855), p. 7.

' Hobson claimed O'Connor still owed money for Irish election contests. Manchester Examiner, November 6, 1847.

${ }^{2}$ J. W. Knapp and E. Omler, Cases of Controverted Elections in the Twelfth Parliament of the United Kingdom (London, 1837), pp. 393-94, quoted by Glasgow, loc. cit., p. 58.

${ }^{3}$ A. M. Hadfield, The Chartist Land Company (Newton Abbot, 1970), p. 64; J. MacAskill, "The Chartist Land Plan", in: Chartist Studies, ed. by A. Briggs (London, 1959), p. 331.

4 Northern Star, January 16, 1841, p. 1, but examples can be found throughout O'Connor's career, whenever the legitimacy of his leadership is under challenge. 
considering the career of almost all other radical working-class or Chartist papers, was the prospect of a long period of losses before the paper would break even or show a slight profit. The phenomenal success of the early years of the Star was the exception to the rule. O'Connor later pointed out that he had expected and had been willing to lose ten pounds a week on the Star, which was the sum Hobson, Hill and he had estimated would be lost. When the Star proved the most successful paper in the country, the profits were spent on agitation; "every $£ 10$ made, was spent in travelling, agitating, donations, subscriptions [...] in support of the cause." 1 If the scheme was speculative, then the proprietor stood to lose as much, if not more, than anyone.

Nor were the shareholders dissatisfied with the arrangements or the management of the paper. At a dinner of shareholders given in Halifax in May 1838, to celebrate the first half year of the Star's career, the chairman, Henry Rawson, remarked "that the liberality of the proprietor was even greater than the shareholders had any just right to expect". Toasts were proposed to the success of the Star, along with the health of O'Connor, Hill and O'Brien, and it was resolved that the interest awarded to the shareholders had proved a spur to radicalism. ${ }^{2}$ At the end of 1838 O'Connor offered to buy up any shares. ${ }^{3}$ As Dorothy Thompson has observed, "in view of the history of most ventures in radical newspaper publishing in the nineteenth century, the shareholders might well have considered themselves fortunate in having their money returned at all." 4 The fact that the Star was not run by a committee of shareholders did not necessarily mean it was subject to less popular control. O'Connor may have correctly believed that this was neither the most efficient form of management nor the most effective manner of public control..$^{5}$ Before it folded in 1840 , the London-based "moral-force" Charter, which was organized upon a

1 Ibid., January 30,1841, p. 7 .

2 Ibid., May 5, 1838, p. 5. Also November 17, p. 8; Dewsbury Radical Association celebrated the Star's anniversary.

${ }^{3}$ Ibid., November 3, 1838, p. 4; April 24, 1841, p. 7: O'Connor had paid off $£ 270$ of original shares; January 18,1845, D. 4 : O'Connor reported about $£ 400$ of original $£ 690$ in shares had been bought up and interest paid; also O'Connor, Reply to John Watkins's Charges, op. cit., p. 16.

4 D. Thompson, "La presse de la classe ouvrière anglaise, 1836-1848", in: La Presse Ouvrière 1819-1850, ed. by Jacques Godechot (Paris, 1966), p. 25. Mrs Thompson's article has influenced this essay substantially at many peints.

- Northern Star, July 11, 1840, p. 7. O'Connor claimed joint-stock ownership led to splits and cited the failure of the Charter. "I have always had, and always shall have, so long as I am concerned with the Star, undivided possession, and individual responsibility. [...] There never was, there never will be, so truly a Democratic Journal as the Northern Star." 
joint-stock committee basis, attributed its failure to this form of organization. ${ }^{1}$

If O'Connor had to pose as a man of greater wealth than he was, if he had to incur debts which might have been difficult to repay, if Feargus had to use some Irish bluff and charm, the fact remains that he launched one of the great radical journals of British history. The conception of the Star was not the reckless Irish adventure which Place and some later historians believed. O'Connor was a shrewd leader, who saw the imperative need for a national newspaper of the working class. He knew the North and its people, he recognized the problems inherent in organizing from London, and he deduced from where he could launch a successful working-class paper. "Never was a journal started more opportunely. It caught and reflected the spirit of the times", commented Gammage. ${ }^{2}$ The continued success of both O'Connor and his paper was dependent on that ability to react with great sensitivity to "the spirit of the times".

\section{III}

The foundation of the Star grew out of the general desire of the leading radicals of the West Riding and South Lancashire to reflect the growing militancy of the Northern working class, spread the resistance to the New Poor Law and propagate the principles of traditional radicalism. The radicals at Ashton-under-Lyne welcomed the new paper, as they believed it to be "highly desirable that the lovers of freedom, throughout the British dominions, should have some common rallying point for the muster of their forces - some common organ for the expression of their otherwise isolated opinions and wishes which might bestow upon them that influence and power which are only to be derived from unity and concentration, and without which all our efforts will be unavailing". ${ }^{3}$

For O'Connor the project marked the culmination of two years of

1 Charter, March 1, 1840, p. 1. For the establishment of the Charter upon a joint-stock committee basis, see Place Collection, Set 66, handbills, "Prospectus of a Weekly Newspaper Entitled the Charter"; "An Address from the Provis ional Committee for the Establishment of a Weekly Newspaper Entitled the Charter". O'Brien's Operative was organized on a similar basis, 4000 five-shilling shares were to be sold, Operative, November 4, 1838, p. 1. The shareholders of the Charter seem to have had little control over the paper's editor, William Carpenter, whom they blamed for the paper's demise, Charter, March 15, 1840, p. 1. Ultimately the Charter depended upon the largesse of wealthier men such as Place, Dr Black and Colonel Thompson, see correspondence, Place Collection, Set 56 (January-April 1841), ff. 15-17.

2 Gammage, History of the Chartist Movement, op. cit., p. 16.

3 Northern Star, December 16, 1837, p. 3. 
agitation in London, the North of England and Scotland attempting to bring some general coherence to local protest and radical organization. The establishment of the Star was crucial to the generalization of local radical agitation. As O'Connor wrote,

"Antecedently to the establishment of the 'Star', local opinion was organised at great personal expense, and with much labour and uncertainty. Grievances were matter of mere oral tradition; and local grievances were resisted by the brave in their respective neighbourhoods, at great risk. STEPHENS was not known beyond the narrow limits of a portion of Lancashire, and even there, not truly known; his eloquence astounded the ear, but never reached the hearts of those who heard not. [...] OASTLER reigned in the hearts of those within his narrow circle; but how much has the 'Star' increased its circumference? BusSEY was but known to Bradford. Pitkethly [...] could see at one glance the limits of his influence. FlETCHER was buried. SANKEY was unheard of. MACDOUALL would have remained unknown. Frost would never have been heard of. O'CoNNOR would have been prematurely consigned to the grave from over-exertion. The talents of HuLL [...] would have smouldered in the pulpit, and the immediate precincts of his own locality; and many others would have died unknown, $[\ldots]$ had it not been that all were here represented in one common mirror, truly reflected". 1

O'Connor was not the only radical leader who felt the need for a newspaper in order to intensify and coordinate the rising tide of working-class protest. Over a year before the first edition of the Star, its editor, William Hill, had attempted to start a paper at Hull along with a group of local working men, to be called The Yorkshire and Lincolnshire Liberator and Hull Political Register. ${ }^{2}$ O'Connor frequently spoke at meetings with Hill, and not only knew about the scheme but supported it. ${ }^{3}$ Both men were in contact with the same

1 Ibid., April 27, 1839, p. 4.

2 Place Collection, Set 70, ff. 619-21, prospectus addressed to the "Unrepresented Men of England", proposing to launch the Liberator from Hull. Also see enclosed letter of Henry Collinson to Place, December 27, 1836, asking Place for a contribution and informing him that "Mr. Hill of Bradford, Yorkshire to be the Editor of the paper".

Leeds Times, January 14, 1837, p. 8; January 21, p. 5 : O Connor and Hill at Bradford and Barnsley together; February 11, p. 5; February 18, p. 5: Hill touring Yorkshire. At the Bradford dinner at which O Connor was the main speaker, many of the radicals who were to be instrumental in launching the Star were present, including Pitkeithley and Oastler from Huddersfield, Henry Rawson from Halifax, as well as J. Douthwaite, Chris Wilkinson, Samuel Bower and John Jackson, all from Bradford. 
groups of Northern radicals. Around the same time that O'Connor approached Hobson, May 1837, with his idea for a newspaper, Hobson was himself planning an Oastlerite journal to be called The Justifier, as an alternative to the middle-class radical Leeds Times. ${ }^{1}$ The impression has been given that $O^{\prime}$ Connor merely took over a scheme of Hill's based firstly upon Hull and then Barnsley. Perhaps O'Connor gained some inspiration from Hill's scheme, as well as observing its shortcomings. Naturally O'Connor was happy to have the money which Hill and his friends had raised for the Hull project transferred to the cause of the Star, as were Hill and the Hull radicals to find an alternative newspaper since their own plans had failed to come to fruition. But there is no reason to confuse the two newspaper projects, nor propagate debates as to whether O'Connor took over Hill's initiative. ${ }^{2}$ Obviously Hill, O'Connor and others were thinking along similar lines. However, O'Connor's plan was of a different order from Hill's. Whereas Hill's plan was local, the novelty of O'Connor's conception was that of founding a national working-class organ outside London, basing a national paper in a local radical stronghold and using it to mobilize a movement. From the outset O'Connor invisaged something greater than a provincial paper. "The Northern Star is not, nor was it ever intended to be, a mere Leeds paper. 'Tis a national organ; devoted to the interests of Democracy in the fullest and most definite sense of the word; and it is, consequently, supported by every true Democrat in every place where it became known", wrote O'Connor in May $1838 .^{3}$

Indeed it is difficult to point to any other radical leader besides

1 Ibid., May 13, 1837, p. 4.

${ }^{2}$ Glasgow, loc. cit., pp. 60-61. Glasgow bases this assertion upon Alexander Paterson, "Feargus O'Connor and the Northern Star", in: Leeds Mercury, February 24, 1900, Supplement, p. 1. Paterson also wrote an earlier letter on Rev. Hill and the Star, in Newcastle Weekly Chronicle, March 10, 1883, p. 2. However, Glasgow has misread the evidence. Hill's project was based on Hull. It may be that O'Connor considered publication from Barnsley. It also should be noted that despite the bitter hostility which developed between Hill and O'Connor after Hill's dismissal in 1843, Hill never claimed that O'Connor had merely taken over his scheme. According to Hobson, Hill and O'Connor, Hill was approached after the plans for the Star were well off the ground. Both Hobson and O'Connor state that it was Hobson who recommended Hill as editor. See William Hill, The Rejected Letters (n.p., 1843) (copy in Seligman Collection, Columbia University); id., A Scabbard for Feargus O'Connor's Sword (Hull, 1844); F. O'Connor, A Letter from Feargus O'Connor, Esq., to the Rev. William Hill. In Answer to Several Charges Contained in Recent Documents Published by that Gentleman (London, 1843); Manchester Examiner, November $6,1847$.

3 Northern Star, May 26, 1838, p. 4. 
$\mathrm{O}^{\prime}$ Connor who combined the qualities necessary for the establishment of a paper like the Star by late 1837 . He had been agitating the country for two years upon radical principles, had won the confidence of key radical leadership in the most important localities, he had been a thoroughly radical MP, and was a gentleman of some wealth, a personal friend of Oastler and part of the platform triumvirate who fired the anti-Poor-Law movement, while adhering to the primacy of the traditional radical demand for universal suffrage. Writing in honour of the Star's fifth anniversary, Hill explained the difficulties which he had encountered when trying to establish a newspaper, and paid tribute to O'Connor's key role in launching the Star.

"I set myself, therefore, to see the people in possession of an organ which, trumpet-tongued, might speak their will, and utter their complaints. I laboured hard for it, and expended much more time and money than I could afford; but there was wanting either power or energy amongst the people. The work progressed slowly, and I was about retiring in despair from the attempt, when Providence brought me in contact with your indomitable Champion, and true friend, O'ConNOR, who had seen and felt the same lack of means to make principle stand firmly on its own basis, and throw overboard adventuring experimentalism. His dauntless spirit, in the face of a most uninviting prospect, resolved to remedy the grievance at all hazards; and the Northern Star was hung up in the political hemisphere". ${ }^{1}$

The success of the Star depended upon the active support of a group of Northern radicals largely centred on the towns and villages of the West Riding of Yorkshire. These were men with whom O'Connor had shared platforms, organized meetings and discussions, and cooperated in founding Radical Associations. From Huddersfield not only could O'Connor rely upon the support of Oastler and Hobson, but experienced radicals such as Lawrence Pitkeithley, John Leech, Chris Tinker, Stephen Dickenson; from Leeds George White and William Rider; at Bradford Peter Bussey, John Jackson, Samuel Bower, John Douthwaite, James Ibbetson; at Halifax Henry Rawson, William Thornton and Ben Rushton (two long-serving radicals), Robert Sutcliffe, Robert Wilkinson, T. Cliff; and the veteran T. S. Brooke of Dewsbury. Barnsley was already the strongest centre of O'Connorite support by

1 Ibid., November 19, 1842, p. 4. Hobson paid similar tribute: "No man, excepting the proprietor of the Northern Star, could have made the paper anything like what it is, or have overcome the almost insurmountable obstacles opposed to the establishment of an organ so entirely opposed to all existing abuses." Ibid., October 5, 1839, p. 4. 
1837. Here Feargus called upon the support of the Radical Association, led by men such as Peter Hoey, Joseph Crabtree, Lingard, Aneas Daley, George Utley, and the veteran radicals John Vallance and Arthur Collins. ${ }^{1}$ It may have been the original intention of $\mathrm{O}^{\prime}$ Connor to start his paper from Crabtree's large room at Barnsley. ${ }^{2} \mathrm{O}^{\prime}$ Connor also looked to South Lancashire contacts for assistance - J. R. Stephens at Ashton, Manchester friends such as the old Huntites James Wheeler and Rev. James Scholefield. ${ }^{3}$ At Oldham Jessie

${ }^{1}$ For O'Connor's contact with these radicals, see Leeds Times, 1836-38. For Oastler, see C. Driver, Tory Radical: The Life of Richard Oastler (New York, 1946). For Hobson, see obituary in Huddersfield Weekly News, May 13, 1876; J. F. C. Harrison, "Chartism in Leeds", in: Chartist Studies, op. cit., pp. 67-68; id., Robert Owen and the Owenites in Britain and America, The Quest for a New Moral World (London, 1969), p. 226, note 2. For Pitkeithley, see obituary in Huddersfield Chronicle, June 5, 1858; Newcastle Weekly Chronicle, September 27, 1879; Harrison, Robert Owen, p. 227, note 1. For the important behind-thescenes work which a radical like Pitkeithley undertook on the Star's behalf, see HO 40/47, ff. 529ff., letters from Pitkeithley to Joseph Broyan of Sutton-inAshfield, seized by the local magistrates in 1839. Pitkeithley had been a friend of Hunt's and played a key role in the defence movements for the Dorchester Labourers and Glasgow Spinners. He was a close friend of both Oastler and O'Connor. John Leech was the manager of Pitkeithley's woollen draper's shop. For George White, see K. Geering, "George White: a Nineteenth Century Workers' Leader" (Sussex University B.A. diss., 1972); Harrison, "Chartism in Leeds", loc. cit., pp. 70ff., also for William Rider. For Peter Bussey, see Charter, May 5, 1839, p. 229. John Jackson was an old Huntite and among Bradford's oldest radicals, see A Young Revolutionary in Nineteenth Century England: Selected Writings of Georg Weerth, ed. by I. and P. Kuczynski (Berlin, 1971). John Douthwaite had been involved along with O'Connor, O'Brien and John Bell in the radical Central National Association in 1837. James Ibbetson was a victim of the unstamped, see Hollis, op. cit., p. 113. For pre-Chartist radicalism in Bradford generally, see A. J. Peacock, Bradford Chartism [Borthwick Papers, 36] (York, 1969), pp. 8-9. For Ben Rushton and William Thornton, see Benjamin Wilson, The Struggles of an Old Chartist (Halifax, 1887); E. P. Thompson, The Making of the English Working Class (London, 1963), pp. 398-400. For the Barnsley radicals, see John Hugh Burland, "Annals of Barnsley", manuscript in Barnsley Reference Library; "The Life and Times of John Vallance", in: Barnsley Times, April 15 - July 29, 1882. I would like to thank Fred Kaijage and Dorothy Thompson for drawing my attention to these last two sources.

2 Burland, "Annals of Barnsley", f. 71; Paterson, "Feargus O'Connor and the Northern Star", loc. cit.

${ }^{3}$ For Stephens, see J. T. Ward, "Revolutionary Tory: The Life of Joseph Rayner Stephens of Ashton-under-Lyne (1805-1879)", in: Transactions of the Lancashire and Cheshire Antiquarian Society, LXVIII (1958), pp. 93-116. For James Wheeler, see obituary in People's Paper, September 23, 1854, p. 1. Both Wheeler and Rev. James Scholefield had been active in radical politics from before Peterloo. The Hunt Monument erected by the Chartists in 1842 stood in the yard of Scholefield's Manchester chapel. 
Ainsworth and James Holladay, both members of O'Connor's Oldham election committee in 1835, became the Star's two sureties, and England's "oldest radical" John Knight became a regular correspondent until his death in 1838.1

These were just some of the men who since 1832 had been leading the opposition to the Whigs. They had taken prominent part in the unstamped agitation, the defence of trade unions, the ten-hours movement, the anti-Poor-Law agitation and all aspects of local radicalism. It was this group of leaders who linked the struggles of 183238 and earlier traditions to Chartism. We can only begin to suggest the enormous contribution in terms of political experience and radical tradition which such men brought to Chartism. To these radicals O'Connor appealed with his newspaper scheme, not only to take up shares, but for propaganda, reports of meetings, agencies of distribution and organization. Thus the foundations of the Star can not be divorced from O'Connor's earlier radical involvement. In its establishment and initial success can be seen the fruits of several years hard work during the pre-Chartist years which coincided with the aims and activities of many local radicals, especially in the North.

Although the conception of the Star was national, it needed a strong local base from which to grow. Leeds and the surrounding district provided such a base. Joshua Hobson's unstamped Voice of the West Riding, published from Huddersfield, 1833-34, had drawn on the same areas for support - Huddersfield, Bradford, Leeds, Halifax and Barnsley. ${ }^{2}$ Almost half the Star's early circulation of over 10,000 copies a week came from Leeds, Bradford, Halifax and Huddersfield. ${ }^{3}$ Together with Hull and Barnsley these were also the towns where most of the Star's shares were taken up. Hobson's Voice of the West Riding was an important precursor to the Star. Dr Wiener has described the Voice as "one of the liveliest and most controversial of the illicit provincial journals. Its tone was one of extreme class animosity. [...] And in the area of political and social criticism, the Voice anticipated 'physical force' Chartism".. Hobson's earlier journal had been a vital experience in the development of West Riding radicalism, and

1 For Jessie Ainsworth, coal-owner, James Holladay, master-spinner, and John Knight, see J. Foster, Class Struggle and the Industrial Revolution: Early industrial capitalism in three English towns (London, 1974). Also see obituary for Knight in Northern Star, September 8, 1838, p. 8; September 22, p. 7.

2 Hollis, op. cit., p. 109

${ }^{3}$ Northern Star, March 31, 1838, p. 4. Weekly circulation figures for the previous six weeks, average of 10,659 a week, of which: Leeds 1,903, Bradford 836, Halifax 837, Huddersfield 1,000. Presumably Barnsley would have been on par with Bradford and Halifax.

- Wiener, op. cit., p. 190. 
Hobson's association with O'Connor's new paper, along with that of William Rider, who had edited the Voice during Hobson's spells in prison, was no doubt important in securing the allegiance of the West Riding radicals.

The West Riding was not the only locality to give birth to a radical working-class newspaper at the end of 1837 . The first edition of the Northern Liberator was published from Newcastle a month before that of the Star, October 14, 1837. Like O'Connor Augustus H. Beaumont, its original proprietor and former radical ally of O'Connor, was impressed by the militancy of the North compared with London. Acting upon this he moved the press of his short-lived Radical to Newcastle." Although a very fine newspaper, the Liberator never was a national organ like the Star. ${ }^{2}$ London was a more difficult place from which to mobilize public opinion than a town like Leeds or Newcastle. An article in the Star in 1850 outlined the reasons for this.

"London is always the last to stir, or when it takes the initiative, such is its overwhelming bulk, and the consequent segregation of its parts, that no powerful and well compacted concentration of popular energy is produced. [...] When you do get a large meeting it is not London, but the friendly parties who reside in different parts of it that are brought together by a common feeling. The outer public is scarcely stirred. How different all this is in a provincial town! There the movement, if popular at all, is a real one, and carries all classes with it. The workshops, factories, warehouses, counting-houses, shops and street corners, all reflect its influence."3

From London in 1838 O'Brien could only report; "while you are

1 W. H. Maehl, Jr, "Augustus Hardin Beaumont: Anglo-American Radical", in: International Review of Social History, XIV (1969), pp. 237-50. Beaumont sold the Liberator to Robert Blakey for $£ 500$ in January 1838. Blakey claimed the machinery for producing the paper had originally cost $£ 900$, The Memoirs of Dr. Robert Blakey, ed. by H. Miller (London, 1879), p. 108. Also see W. E. Adams, Memoirs, op. cit., I, p. 179; for the post-Beaumont period of the Liberator's career, see T. A. Devyr, The Odd Book of the Nineteenth Century (Greenpoint, New York, 1882).

2 Although the same price as the Star, the Liberator was only half its size. In July 1839, at the height of the Chartist agitation, it was enlarged to an eightpage paper like the Star. However, it never had the wide range of reporting of the Star. Reports outside the North-East were usually quoted from the Star. As for quality, Gammage, op. cit., p. 18, commented: "It was conducted with spirit and ability; its original matter was superior to that either of the Star or the London Dispatch". In May 1840 the Liberator merged with the Champion. 3 Northern Star, December 21, 1850, quoted by D. Read, The English Provinces, 1760-1960: A study in influence (London, 1964), p 117. 
rousing the sections in the North, we in London, have fallen into a sort of Endymion's sleep."1 The Star hoped that the spirit of Northern radicalism would set an example for the Metropolitan radicals.

"The tone which the men of Lancashire and Yorkshire have assumed upon the all important question of labour and capital, and their firm resolve to do their own work will we trust, instill some spirit into the Whig-ridden working-men of the Metropolis. We challenge them to action. We ask them for work, not words. They are a century behind us. What they talk about, we do. While they throw themselves into the arms of the Aristocratic leaders, we in Yorkshire and Lancashire wish to see the work done by the people themselves." 2

Perhaps part of the success of the Star was its appeal to sense of provincial superiority. ${ }^{3}$

The publication of the Star coincided with the height of popular resistance to the New Poor Law in the North. This was reflected in both its early circulation pattern and content. South Lancashire provided the other main area of anti-Poor-Law protest and early support of the paper. ${ }^{4}$ The case of the Glasgow Spinners was the other prominent issue which filled the early columns of the Star. O'Connor had put himself at the head of both protests, alongside Oastler and Stephens. ${ }^{5}$ It was later claimed that $O^{\prime}$ Connor owed the initial success of the Star to his reporting of the speeches of Stephens and Oastler,

1 Northern Star, April 7, 1838, p. 4.

2 Ibid., December 2, 1837, p. 1; also see December 16, p. 4.

3 Many provincial radicals saw London as the centre of national corruption, and contrasted the relative inactivity of the capital with the action of the North. See, for instance, O'Connor's speech reported in Northern Star, July 21, 1838, p. 3, or the letter from a "Yorkshire Chartist" (John Watkins) ibid., April 3, 1841, p. 7.

4 See N. C. Edsall, The Anti-Poor Law Movement (Manchester, 1971), pp. 169-70. The agents listed in Northern Star, December 2 and 16, 1837, were mostly from the West Riding and South Lancashire.

5 Northern Star, January 20 - February 17, 1838, published a complete account of the Glasgow Spinners' trial. Place commented: "The case of the men [Glasgow Spinners] was dealt upon, and commented on in the Northern Star, and as it was at the time a subject about which most of the Trades in Great Britain took an interest, it helped to a considerable extent to promote the sale of the paper. The introduction of the new Poor Law into the Northern counties was another subject of excitation, it caused many riots and being opposed in every possible way it also tended to increase the sale of the paper. O'Connor, Oastler and Stephens made common cause in public meetings; by publications, and correspondence to embarrass the proceedings of the Poor Law Commissioners and were very successful." British Museum, Add. Mss 27820, f. 153. 
and to a certain extent this was undoubtedly true. ${ }^{1}$ Although the Leeds Times and the Manchester and Salford Advertiser carried antipoor-law news, both middle-class radical papers were exhibiting an increasing alienation from the rhetoric of violence used by the leaders of the anti-Poor-Law movement, especially the speeches of Stephens. ${ }^{2}$ In contrast, the Star filled its pages with the blood-curdling exhortations of Ashton's "political preacher" and the intimidating letters of the "Factory King". Although this helped to sell papers, it was also hazardous. Publishing the revolutionary utterances of Oastler and Stephens was a bold act. By the third edition Lord John Russell was considering prosecuting O'Connor for the publication of seditious libel. The law officers had no doubts about the illegality of Oastler's letter and the speeches published in the Star of December 2, 1837, but feared a jury might not convict. Instead the Government had to wait for the infringement of a minor technicality and an absurd libel against the Warminster Board of Guardians in order to strike. ${ }^{3}$

Despite this coverage the Star was never intended principally as a journal of the anti-Poor-Law movement, nor was it. Unlike Oastler and Stephens, the Star and O'Connor always supported a wider and more traditional radical programme headed by the demand for universal suffrage. ${ }^{4}$ For this reason O'Connor and the Star were crucial agents in transferring the energy of the anti-Poor-Law agitation into Chartism. ${ }^{5}$

1 Champion, October 27, 1839, pp. 4-5; Northern Star, November 2, 1839, p. 4. 2 For instance, Manchester and Salford Advertiser, January 27, 1838, p. 2, condemns Stephens's violent rhetoric and compares this to the "far more legitimate model of radicalism" of Thomas Attwood and the Birmingham Political Union. Northern Star, February 10, 1838, p. 1, defends Stephens. N. C. Edsall, op. cit., pp. 120-21, is thus mistaken in his assertion that the Star did not fill a gap in terms of the anti-Poor-Law movement.

${ }^{3} \mathrm{HO} 48 / 32$, case 13 ; HO 49/8, ff. 214-16. Local authorities immediately drew the attention of the Government to the "seditious" speeches published in the Star: Major Phillips to General Jackson, Bradford, December 3 and 11, 1837, HO 40/35, ff. 63-64, 76-77; R. Baker to Poor Law Commissioners, Leeds, January 5, 1838, Ministry of Health Papers, 12/14830, Public Record Office; ibid., $12 / 14720$ (Bradford); Northern Star, January 6, 1838, p. 5; F. C. Mather, "The Government and the Chartists", in: Chartist Studies, p. 375. For later proceedings, see HO 48/33, case 22; HO 49/8, ff. 289-90, 307-08, 312-15; Northern Star, April 20,1839, p. 4; July 27, p. 6. O'Connor was eventually sent to prison largely for speeches published in the Star, see Treasury Solicitor's Papers 11/813-14, 817, Public Record Office; Northern Star, March 21 and May 16, 1840, for reports of the trial.

4 From the first edition, Northern Star, November 18, 1837, p. 1, O'Connor placed universal suffrage as the first demand. By October 1838, the anti-PoorLaw protest was regarded as "only one grievance among many", October 13, 1838, p. 4.

5 M. E. Rose, "The Anti-Poor Law Movement in the North of England", in: Northern History, I (1966), p. 88; Edsall, op. cit., pp. 169-72. 
In the early months of 1838 , Hill's editorials, O'Brien's weekly letters and $O^{\prime}$ Connor's speeches all reiterated the need for working-class unity behind the single demand for universal suffrage.

\section{IV}

In terms of circulation the Star was almost an immediate success. By December 26, 1837, they were receiving a regular weekly supply of 10,000 stamps. $^{1}$ The sixth number, January 6,1838 , sold over 10,000 copies, and by March a steam press was in operation. ${ }^{2}$ By the end of 1838 the Star had established itself as the most widely circulating provincial paper in Britain - selling more copies than either its neighbour and arch-enemy, the Leeds Mercury, or the Manchester Guardian, which was published bi-weekly. ${ }^{3}$ The arrest of J. R. Stephens and the gathering of the Convention in the early months of 1839 increased sales still further, and by April the offices of the Star had to be enlarged and a new press constructed. ${ }^{4}$ In the hectic weeks following the Bull Ring Riots at Birmingham, in July 1839, and with the prospect of a call for a national general strike from the Chartist Convention, sales perhaps reached 50,000 copies a week. ${ }^{5}$ Although by the end of 1839 sales had settled down to 14,000 a week, the overall weekly average for 1839 was 36,000 copies. $^{6}$ No radical journal since Cobbett's Twopenny Trash, with the possible exception of the 1d Cleave's Weekly

1 Northern Star, February 3, 1838, p. 5.

2 Ibid., January 6, p. 4; March 31, p. 4.

${ }^{3}$ Ibid,, November 24, p. 4. As early as May 26, p 4, the Star was claiming a higher circulation than the Leeds Mercury. With the Star's success sales of the radical middle-class Leeds Times fell seriously, Read, Press and People, op. cit., p. 94. For the Star's circulation history see Appendix. For comparative figures, Report of the Select Committee on Newspaper Stamps, 1851, Appendix 4.

4 Northern Star, February 2, 1839, p. 4, claimed that the January 26 edition of the paper sold 17,640 copies; March 9, p. 4, announced that the average weekly sales over the previous three months had been around 12,000 copies; and April 20, p. 4, claimed they were "printing more weekly, than were ever sent out of a paper our size, from a single printing machine".

- Estimates of the Star's circulation high vary. Hovell, The Chartist Movement, pp. 173, 269, note 1, estimated 48,000 (February-May 1839). Benjamin Wilson, The Struggles of an Old Chartist, op. cit., p. 3, estimated 60,000, as did Frank Peel, The Risings of the Luddites, Chartists and Plug-drawers, 4th ed. (London, 1968), p. 314. Alexander Paterson, loc. cit., estimated "nearly 50,000". Northern Star, June 1,1839, p. 4 , announced a weekly average over the preceding two months of 32,692; August 17, p. 4, announced 42,000 to be the average weekly sales for the period April-June 1839.

6 Northern Star, February, 22, 1840, p. 4; Appendix. 
Police Gazette in 1836, had reached this number of people. ${ }^{1}$ Certainly no working-class newspaper had ever had so large a circulation. Sales were so great that "the Post Office authorities were in some cases obliged to hire carts or wagons for its transmission, as it occasionally overflowed the restricted accommodation of the mail coaches". ${ }^{2} \mathrm{R}$. J. Richardson's Salford shop was "thronged on Saturday, as there is upwards of 300 Northern Stars sold". ${ }^{3}$

However, circulation figures give an inadequate measure of either the influence or total readership of the Star. The Star was available at clubs and working-class reading rooms, radical coffee houses and Chartist taverns, copies were passed between friends, radicals combined to subscribe and have their copy read aloud at home, in the workshop or at meetings. It is obvious from the highly rhetorical style of the Star's lead articles that the paper was designed to be read aloud. It is impossible to estimate accurately how many people read or heard the Star read. For the unstamped - cheaper than the Star - Dr Hollis has suggested a ratio of twenty readers to every copy. ${ }^{4}$ But estimates of the number of readers per copy of a newspaper in the nineteenth century can be found as high as between fifty to eighty. ${ }^{5}$ In 1838 O'Brien referred to the paper's "ten thousand subscribers, and your one hundred thousand readers"; and by April 1839, the Star claimed 400,000 readers. $^{6}$ In terms of distribution the Star was successful in creating a national audience in less than a year. From the list of agents, reports of meetings and letter columns the national growth of the paper can be followed." The appeal was direct: "Let every town

1 G. D. H. Cole, The Life of William Cobbett, 3rd ed. revised (London, 1947), p. 207, estimated the sale of the Trash (the cheap edition of the Political Register, excluding news items) to have reached between 40,000 and 50,000 in 1816-17; Hollis, op. cit., p. 95, reckons 20-30,000. Hollis, p. 124, has estimated the circulation of Cleave's Gazette to have reached a high of 40,000 a week in 1836. Neither the Trash nor Cleave's Gazette were stamped or carried news. The stamped Political Register was estimated by the Home Office to have sold 20,000 copies a week in 1817 , at the price of $6 \mathrm{~d}$, Hollis, p. 119. The Poor Man's Guardian at its height, 1832-33, sold around 15,000 copies, ibid., p. 118. No Chartist paper came close to the Star's circulation.

2 Daunt, Eighty-Five Years, op. cit., I, p. 268.

3 E. Richardson to R. J. Richardson, February 16, 1839, HO 40/53 (file of intercepted letters to members of the Chartist Convention), f. 928; Mrs Richardson to R. J. Richardson, February 26, 1839, ff. 953-57.

4 Hollis, op. cit., p. 119.

- See Read, Press and People, p. 202; R. K. Webb, The British Working Class Reader (London, 1955), pp. 31-34.

- Northern Star, June 9, 1838, p. 4 ; April 6, 1839, p. 3.

7 For instance, see the list of agents, Northern Star, February 9, 1839. About one hundred localities are represented, by about two hundred agents. Halifax 
briefly address the country through the medium of the Northern Star, and let one and all know our strength, our union, and our determination to die freemen rather than live slaves." 1 Unfortunately, it is impossible to discover the number of copies sent to each district. But the North was by no means the only stronghold. James Guest, Birmingham's radical bookseller and veteran of the unstamped, regularly received three thousand copies a week for the Birmingham area for about three years, and sometimes received as many as six to seven thousand copies. ${ }^{2}$ Improved transport facilities helped the Star create a national character. The Star, printed on Saturday, claimed that it could be delivered in London the same evening. ${ }^{3}$

The readership of the Star was almost entirely working-class. Thus it was dependent on the support of a social group of whose numbers possibly as many as one third were illiterate. ${ }^{4}$ Great pride was taken in this readership: "It is true that the greater part of our readers are to be found in the humble and useful classes of society. We rejoice to think that it is so. We claim no alliance with any other 'system' - we wish not to move in any other 'orbit' - the Northern Star is their luminary, and sincerely do we thank them for having made it shine so brilliantly." The tone of the paper was stridently class-conscious; the language was the razor-sharp rhetoric of class war. The Star filled a radical working-class cultural and educational gap, left partially by the fall of the "pauper press". It inherited part of its readership, discovered a part and also helped to create its own new readers. In a reply to an editorial attack in the Leeds Mercury, it claimed that the paper's rapid success

'proves that the 'working classes' for whom the Northern Star is 'avowedly written', had, previously to its existence, no single provincial organ through which their wants and wishes could be

had no less than seven agents and Birmingham six. By the fifth number of the Star, December 16, 1837, the original West Riding - South Lancashire base had been extended to include Newcastle, Glasgow and Edinburgh.

1 Northern Star, March 24, 1838, p. 3.

2 James Guest, "A Free Press and How it Became Free", in: W. Hutton, The History of Birmingham, 6th ed. (Birmingham, 1861), p. 506. Joshua Hobson, agent for the Ashton-under-Lyne district of South Lancashire, received 1,330 copies a week in February 1839, Northern Star, February 23, 1839, p. 4.

s Northern Star, May 26, 1838, p. 4.

- See R. K. Webb, op. cit.; id., "Working Class Readers in Early Victorian England", in: English Historical Review, LXV (1950); R. D. Altick, The English Common Reader (Chicago, 1957); J. F. C. Harrison, Learning and Living (London, 1961), p. 42, and Pt I in general; M. Sanderson, "Literacy and Social Mobility in the Industrial Revolution", in : Past \& Present, No 56 (1972), would suggest a higher rate of illiteracy in early-nineteenth-century Lancashire. 
adequately expressed, and by which their rights could be duly asserted and their interests maintained. It proves we have discovered or created an entirely new class of readers. The writers in, and the conductors of, the Northern Star, glory in the knowledge that, while they have produced food for the minds of those who lack it, they have not interfered with the 'speculations' of others."1

The Star did not write down to its readers as some of its detractors have claimed, quite the reverse. It was a serious political journal written by highly skilled journalists. On occasion the education of many an artisan or factory hand must have been taxed in reading its pages. The Star was the major institution of Chartist education.

Equally the Star's readers took a pride in its successes, for instance at the well-publicized point at which their circulation surpassed that of the Whig Mercury. Having their own paper was essential to the working-class struggle for a form of cultural independence and control. Feargus urged a Liverpool meeting to "never drink a drop of beer where the Mercury, or Sun, or Times, or Chronicle were taken". ${ }^{2}$ And James Woodhouse, a framework knitter and Nottingham delegate to the first Chartist Convention, told a meeting in 1840: "Do without your pint of ale, but buy the Star; refrain from drinking spirits, but buy the Star; refrain from using tea and coffee and sugar, but buy the Star; and avoid the use of all excisable articles, but buy the Star; and lessen the value of household property, at least one half, but buy the Star."3

The arrival of the Star was an important weekly event. Samuel Fielden, the American anarchist, remembered from his early days in Todmorden, his father, "an earnest champion and admirer of the principles advocated by [...] Feargus O'Connor", relating "that on the day when the newspaper, the Northern Star, O'Connor's paper, was due, the people used to line the roadside waiting for its arrival, which was paramount to everything else for the time being." 4 For many working-class radicals O'Connor's weekly letter was the high-point of the week. W. E. Adams recalled:

"Another early recollection is that of a Sunday morning gathering in a humble kitchen. The most constant of our visitors was a crippled shoemaker, [...] Larry, [...] made his appearance every

1 Northern Star, May 26, 1838, p. 4.

2 Ibid., September 29, 1838, p. 7.

3 Ibid., June 13, 1840, p. 1; Nottingham Review, June 12, 1840, p. 8.

"Samuel Fielden, "Autobiography of Samuel Fielden", in: Knights of Labour (Chicago), February 19, 1887. 
Sunday morning, as regular as clockwork, with a copy of the Northern Star, damp from the press, for the purpose of hearing some member of our household read out to him and others 'Feargus's letter.' The paper had first to be dried before the fire, and then carefully and evenly cut, so as not to damage a single line of the almost sacred production. This done, Larry, placidly smoking his cutty pipe, which he occasionally thrust into the grate for a light, settled himself to listen with all the rapture of a devotee in a tabernacle to the message of the great Feargus, watching and now and then turning the little joint as it hung and twirled before the kitchen fire, and interjecting occasional chuckles of approval as some particularly emphatic sentiment was read aloud."1

The Sunday-morning reading of the Star, and the informal discussions and debates which arose from its contents, were regular affairs to which thousands looked forward. Ben Brierley, in his youth a handloom weaver of velvet in the South Lancashire village of Failsworth, later wrote:

"The Northern Star, the only newspaper that appeared to circulate anywhere, found its way weekly to the Cut side, being subscribed for by my father and five others. Every Sunday morning these subscribers met at our house to hear what prospect there was of the expected 'smash-up' taking place. It was my task to read aloud so that all could hear at the same time; and the comments that were made on the events foreshadowed would have been exceedingly edifying to me were I to hear them now."

These morning readings were followed by afternoons spent turning his father's grindstone, "whilst rebelliously-disposed amateur soldiers ground their pikes".2 From near-by Oldham Benjamin Grime reminisced: "Very distinctly does the writer remember going weekly on Saturdays, from North Moor, across Tommyfield, to 'Owd Knight's', for a copy of the Northern Star, which was the joint property of his father and a few of the neighbours. The paper would then be read in some retired place, on the grass if in summer, or it would be read over the 'tot of whoam-brewed' at some of the hush shops which could then be found in every street within a few yards of each other."3 And Ben

1 W. E. Adams, Memoirs, I, pp. 164-65.

2 Ben Brierley, Home and Memories (Manchester, 1886), pp. 23-24. Brierley's main reading in his early years had been Cleave's Gazette, ibid., p. 26.

${ }^{3}$ Benjamin Grime, Memory Sketches: History of Oldham Parliamentary Elections, 1832-53 (reprinted from Oldham Weekly Chronicle, 1887), p. 26. 
Wilson of Halifax recalled: "Amongst combers, handloom weavers, and others politics was the chief topic. The Northern Star was the principal paper, and it was common practice, particularly in the villages to meet at friends' houses to read the paper and talk over political matters."1

The Star was also taken into the workshop. Daniel Merrick, a Leicester stockinger in the 1840's, later drew on his experiences in his pamphlet The Warp of Life and described the atmosphere of a knitters' workshop where "politics were the general theme for discussion and conversation". The customary tea break provided an opportunity for reading and discussion.

"Some would seat themselves on the winders' stools, some on bricks, and others, whose frames were in the centre, would sit on their 'seat boards'. Then they would commence a general discussion upon various matters, political, moral, and religious. After tea a short article would be read from the Northern Star, and this would form the subject matter for consideration and chat during the remainder of the day." 2

Wherever ultra-radical politics were discussed the Star could be found.

Although a serious political paper, the Star adopted some of the techniques of the popular cheap press, principally woodcuts and steelengraved portraits. ${ }^{3}$ For instance, in 1838 portraits of the Glasgow Spinners and the Dorchester Labourers appeared in the paper. Satirical political cartoons were sometimes printed. ${ }^{4}$ A great success was the series of portraits called the "Portrait Gallery of People's Friends", which included Andrew Marvell, Arthur O'Connor, Hunt and Cobbett, along with the heroes of Chartism. A portrait was distributed free with a copy of the paper, to be hung in working-class homes or used to decorate Chartist meeting rooms. Such souvenirs were remembered by Chartists like W. E. Adams. "One of the pictures that I longest remember [...] was a portrait of John Frost. [...] I have been familiar with the picture since childhood, and cherish it as a

1 Benjamin Wilson, Struggles, p. 10.

2 Daniel Merrick, The Warp of Life, or, Social and Moral Threads, A Narrative (Leicester, 1876), pp. 18, 22. Although not strictly an autobiography, the pamphlet is a teetotal-morality tract; obviously Merrick drew on his experiences as a stockinger in this sketch.

${ }^{3}$ Harrison, Learning and Living, op. cit., pp. 30, 101.

4 Northern Star, January 27, 1838, p. 5; May 5, p. 4; see the cartoon "The Goose Show", satirizing O'Connell and the middle-class Leeds Parliamentary Reform Association, ibid., January 23, 1841, p. 1. 


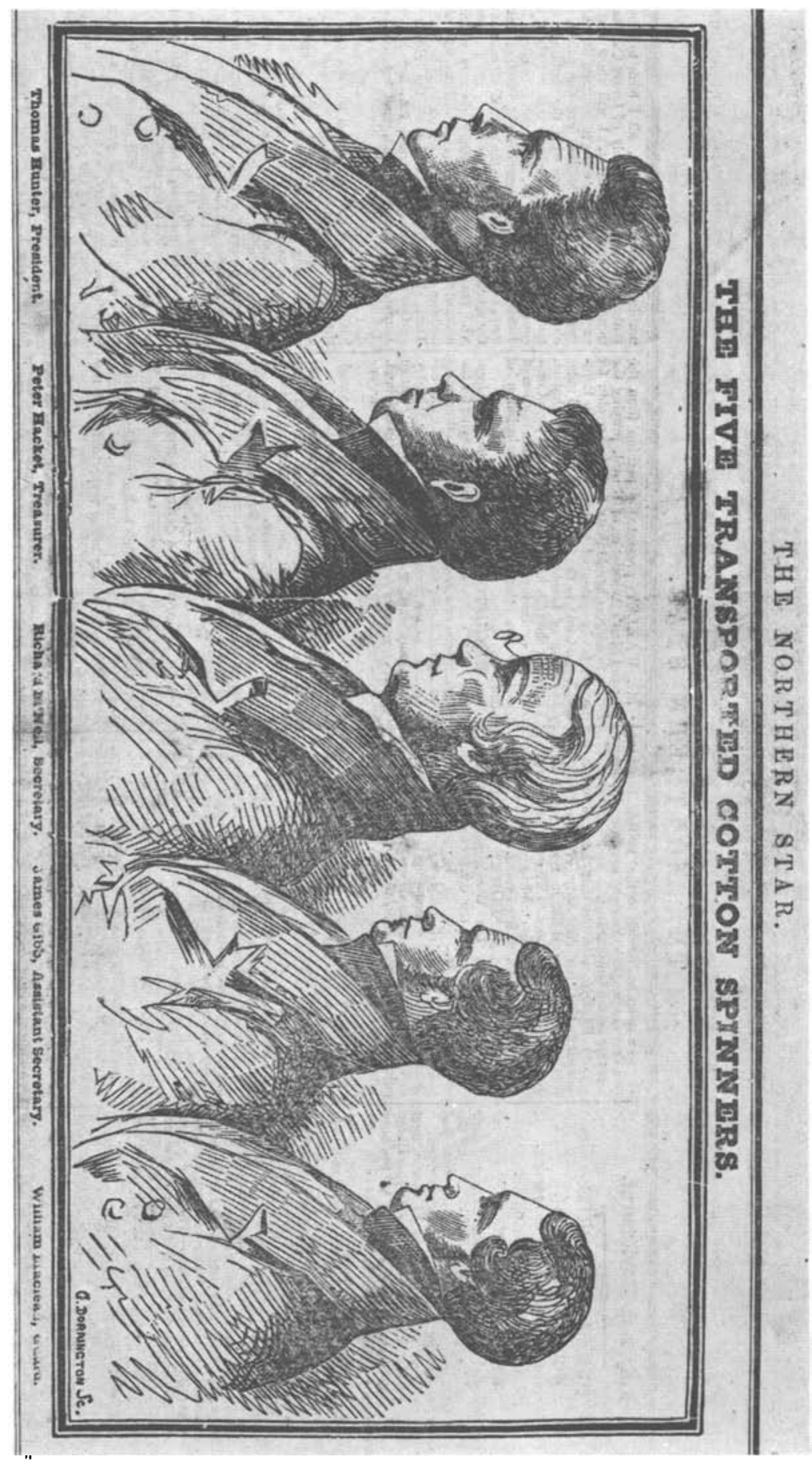


memento of stirring times." 1 Seen as a cheap ploy by middle-class papers like the Mercury, the "Portrait Gallery" was an example of the readiness of O'Connor and his journal to innovate and adapt to popular tastes. There were other "give-aways" from the Star, like the O'Connor Liberation Medals to be distributed with the paper at the slightly higher price of $6 \frac{1}{2} \mathrm{~d}$ to commemorate the freedom of the "People's Champion" from York Castle. ${ }^{2}$ It was acknowledged that such gifts boosted sales. ${ }^{3}$ James Guest sold twice as many copies when pictures were being offered, and sales of other Chartist papers were drastically reduced at Richardson's shop when the Star declared its intention to give out portraits of J. R. Stephens to regular subscribers. ${ }^{4}$ However, the paper's readers were not always satisfied with the editor's choice of worthy candidates for such an honour. The Star had to defend its selection of Sir William Molesworth, MP for Leeds, against workingclass objections, and suggested that in future the people choose their own favourites for the series at their meetings. ${ }^{\bar{j}}$

The relationship between the Star and its readers was close, and the channels of communication were two-way. "If we were to print all the communications we receive, we should, some weeks, want six or seven Northern Stars", commented Hill. ${ }^{6}$ Communications were often received from modest working men who were unaccustomed to addressing journals. John Walker rather apologetically concluded his report of the formation of a Working Men's Association in the South Lancashire village of Mossley: "Gentlemen, as I never attempted to write to public men before, be so kind as to correct my blunders, and let it appear in your 'Star'."7 Letters often ended with an expression of gratitude for the space made available by the Star, "the only medium of expression" - the same phrase so often used in letters to the unstamped. Poems were especially popular. "We have received as much poetry as a donkey could draw; we shall select from it as occasion offers, so let none be jealous, or we will take it by lot."8 Chartist readers were not merely passive recipients of knowledge and news. They were part of the learning process and news-collecting force. It was this involvement which was the format of the Star's

1 W. E. Adams, Memoirs, I, pp. 163-64.

2 Northern Star, November 20, 1841, p. 5.

3 Ibid., May 26, 1838, p. 4.

"James Guest, "A Free Press", loc. cit., p. 506; CEH to R. J. Richardson, March 14, 1839, HO 40/53, f. 1001 ; also Shaw to Home Office, Manchester, December 8,1839 , f. 774 .

- Northern Star, August 4, 1838, p. 3.

- Ibid., May 26, 1838, p. 4.

Ibid., February 24, 1838, p 7.

- Ibid., March 31, 1838, p. 4. 
style of popular democracy. This popularity was not largely dependent on the paper's ability to flatter readers, as some historians have maintained. In the column headed "To Readers and Correspondents", working-class enthusiasts were rather harshly reminded that their letters were sometimes "illiterate", often of no general interest, "overstrained", or had "not the poetic merit to stand the ordeal of criticism". Rev. Hill's praise was not easily evoked. ${ }^{1}$ The columns of the Star were founded neither upon flattery nor strict O'Connorite censorship.

The Star was more than a political paper. It was part of a much larger Chartist cultural experience. It was central to most local Chartist activity. Toasts were drunk to the Northern Star and the freedom of the press, votes of confidence and thanks were passed at meetings for its services, at mass rallies banners celebrated its name, on the anniversary of its establishment dinners were dedicated to its continued success. Chartist meetings often started with readings from the Star, usually the lead editorial or O'Connor's letter, followed by thorough discussion of the issues raised. ${ }^{2}$ By early 1838 the Mossley Working Men's Association announced that they had procured their own reading room, "where they assemble to read the Northern Star, and other newspapers." "We have no secrets; we admit any body, whether they are members or not; we read the news of the week, and discuss it paragraph by paragraph, as it is read. We have a good fire in the room, and so it is that we spend our leisure hours, without ever coming in contact with drunkenness or immorality." 3 Other localities established Northern Star reading societies. ${ }^{4}$ For most localities, with no local press or only a hostile press, the Star took on a great significance through reporting a wide variety of local activity. Even in the exceptional circumstances where a group of local Chartists produced their own paper, it was often regarded as an adjunct to the Star rather than as a substitute. ${ }^{5}$

${ }^{1}$ See Hill's comments to readers, ibid., May 26, 1838, p. 4, or February 9, 1839, p. 4.

2 For instance, most of the Birmingham Chartist weekly meetings in the winter of 1839 began with local leaders reading from the Star, HO 40/50, spies' reports, October-December 1839. This was still common practice in 1841, see reports of Birmingham Chartist meetings, $\mathrm{HO} 45 / 102 \mathrm{~A}, \mathrm{Pt} 1$. Also see "The Reminiscences of Thomas Dunning", ed. by W. H. Chaloner, in: Transactions of the Lancashire and Cheshire Antiquarian Society, LIX (1947), pp. 112-13, 121.

${ }^{3}$ Northern Star, February 3, 1838, p. 5; February 24, p. 7. The Mossley Working Men's Association numbered around fifty at this time.

4 Ibid., February 26, 1842, p. 4. The Northern Star reading societies at Glasgow and Walworth sent donations to the O'Brien press fund.

5 This was certainly true of the Leicester Chartists with regard to the Midland Counties Illuminator, Northern Star, November 14, 1840, p. 2; Midland Counties 
For distribution the Star depended largely on existing local radical booksellers and newsagents. Again the debt to the earlier struggles for a free press is apparent. Many of these agents were veterans of the war of the unstamped. At Ashton-under-Lyne, Joshua Hobson (not to be confused with the Star's publisher of the same name), one of the town's oldest and most respected radicals, a republican and infidel who had sold Carlile's Republican and Lion before he took Hetherington's Poor Man's Guardian and Dispatch, became the local agent. ${ }^{1}$ At Oldham the position quite naturally fell to "Owd" John Knight. Indeed the Star's early list of agents reads like a catalogue of victims of the unstamped. ${ }^{2}$ In London the Star was sold at the shops and radical coffee houses established before and during the unstamped agitation. John Cleave was the main distributor for London, Abel Heywood for the Manchester area, and Hobson for Leeds. At Birmingham, James Guest, radical and Owenite who claimed to have been the first man to sell the unstamped in Birmingham when he sold Carpenter's Political Letter in 1830 from his "Cheap Book Repository", became O'Connor's agent. ${ }^{3}$ Mrs Smith, whose husband was imprisoned in 1836 for selling the unstamped, made the Star available in Nottingham through her "Tradesmen's Mart".4

The agent could also fulfill the role of organizer. A small notice in the Star in March 1838 announced that a Radical Association had been formed at Newton, just outside Manchester, "at the house of Mr. John Hall, agent for the Northern Star in this town". ${ }^{5}$ Sometimes a local working-class radical through a combination of reporting and selling the Star could establish enough financial independence to free

Illuminator, May 1, 1841, p. 47. They believed their paper would "prove a precursor to a more wide dissemination of the Northern Star" in the East Midlands. For a full discussion of the importance of the press to a group of local Chartists, see T. M. Kemnitz, "Chartism in Brighton" (Ph.D., Sussex University, 1969), pp. 179-89.

$1 \mathrm{~W}$. Glover, History of Ashton-under-Lyne and the Surrounding District, ed. by J. Andrew (Ashton, 1884), p. 322. On the death of Ashton's Joshua Hobson the local radicals sent a poem in his honour to the Northern Star, March 24, 1838, p. 6.

2 Northern Star, December 2, 1837, p. 8: along with Ashton's Hobson, John Knight of Oldham and Abel Heywood of Manchester, the West Riding victims Ibbetson, Titus Brooke, C. Tinker were early agents. Four of Birmingham's six agents in 1839 had been prosecuted for selling the unstamped.

3 James Guest, "A Free Press", pp. 493-507. Guest went to prison for selling the unstamped in 1834. He again risked imprisonment in the summer of 1839 for printing the declaration from the Chartist Convention condemning the authorities over the Bull Ring riots.

4 Nottingham Review, January 29, 1836, p. 4; February 5, p. 4.

- Northern Star, March 31, 1838, p. 5. 
himself for full-time Chartist agitation. Such was the case for John Deegan, ex-cardroom-hand and secretary of the Stalybridge Radical Association. ${ }^{1}$ When an existing agent could not be found to sell the Star, a local radical would take on the job. Thomas Dunning, a Nantwich shoemaker and leading local trade unionist, related how he became an agent for the paper.

"I and a dozen or more of my Radical associates wished to subscribe to the Star, and I being secretary of our Chartist association, was requested to order of $\mathrm{Mr}$. Griffiths, bookseller, the only newsagent in the town at the time, the required number of Stars. I requested Mr. G. to supply me with fifteen copies of the Northern Star weekly, and for which I offered to pay him a quarter of a year in advance. He declined taking the order in a most contemptuous manner, with, 'Oh! Ah! a Radical paper, I believe. I am a stamp officer and will not order it, etc.' [...] On Mr. Griffiths' refusal to order the Star I wrote to the publisher of that paper, requesting him to say whether under the circumstances, he would supply me direct from the office. Mr. Ardill, the clerk, replied that he should be glad to send any quantity I might require at wholesale price. I immediately sent order and cash, and from that moment, thanks to Mr. Tory Griffiths, I became a newsagent."2

Comprehensive reporting was one of the major factors in the Star's successful creation of a national medium of Chartist communication. C. D. Collet, in his evidence for the Select Committee on Newspaper Stamps in 1851, emphasized the importance of news.

"I may add, also, that finding they are unable to have cheap newspapers, many of the working classes will club together to take newspapers, even when they do not altogether approve of them [...]. I know that many persons took the Northern Star because it was the only newspaper that gave accounts of the Chartist meetings, and yet those very persons very much disapproved of the paper itself, of a great deal that appeared in it, and of the conduct of its proprietor; but finding that it was the only newspaper which would record the movements of the working classes, they found it necessary to take the paper in."3

1 The middle-class press was very scornful of such independence: "It is more pleasant for bim [Deegan] to get drunk as chairman of a dinner, as president of a tavern club [...] than piece laps in the card room, and earn his bread by the sweat of his brow", Manchester Times, June 9, 1838, p. 3.

2 "The Reminiscences of Thomas Dunning", loc. cit., p. 112.

${ }^{3}$ Report of the Select Committee on Newspaper Stamps, p. 152. 
In the Star's columns ordinary working people were accorded the status of men and women who mattered. Gammage noted: "the Star was regarded as the most complete record of the movement. There was not a meeting held in any part of the country, in however remote a spot, that was not reported in its columns, accompanied by all the flourishes calculated to excite an interest in the reader's mind, and to inflate the vanity of the speakers by the honourable mention of their names. Even if they had never mounted the platform before, the speeches were described and reported as eloquent, argumentative, and the like; and were dressed up with as much care as though they were parliamentary harangues fashioned to the columns of the daily press."1

This was one of the great differences between the unstamped press and the Star. Whereas the unstamped often had little news or had to quote news from London middle-class journals, the Star was a real newspaper which could compete with any adversary for coverage. Hetherington had never been able to cover news outside London satisfactorily. ${ }^{2}$ In contrast, the Star boasted in 1841: "This is our strength. [...] The Star has more original matter than any ten papers in the Kingdom." It claimed to spend $£ 500$ a year on reporting, more than any paper except the Times. ${ }^{3}$ But reporting was also an activity which involved local radicals, who were invited to send reports of their meetings and discussions to the Star. Thus the cost of reporting does not adequately reflect the wide range of coverage, since much of it was dependent on the efforts of unpaid local Chartists. ${ }^{4}$ Fullness, accuracy and speed of reporting were essentials to the Star. ${ }^{5}$ Through

${ }^{1}$ Gammage, op. cit., p. 17.

2 Hollis, op. cit., p. 261.

${ }^{3}$ Northern Star, January 9, 1841, p. 4. However, it seems likely that the major London daily papers spent considerably more on reporting than the Star.

- Sometimes O'Connor paid local radicals to act as regular correspondents, such as Deegan at Stalybridge or William Griffin at Stockport in 1840. Joseph Crabtree of Barnsley was paid $£ 10$ a year to send reports of the Barnsley radical meetings, HO 20/10. But generally the Star depended on local leaders to forward material. Thus, for instance, the Star carried no reports of a Bolton miners' strike because the Lancashire leaders had sent no communications to the paper, Northern Star, November 14, 1846, cited by R. Challinor and B. Ripley, The Miners' Association, A Trade Union in the Age of the Chartists (London, 1968), p. 196.

5 Thomas Frost, Forty Years' Recollections (London, 1880), pp. 119-20, contrasted the fallacious twelve-line report of a meeting of the Croydon Chartists in 1842 published in the liberal South-Eastern Gazette with the full report of the Star, whose reporter, unlike that of the Gazette, stayed for the entire meeting. As for currency of news, on occasion Feargus claimed he had to complain to Hobson that the Star looked as "if it was taken from an old almanac", A Letter from Feargus O'Connor, Esq., to the Rev. William Hill, op. cit., p. 13. Accuracy of reporting had been generally improved in the 1830's. Harland's shorthand 
comprehensive local reporting, local and national Chartist themes were merged. As well as integrating local and national activity, the Star's reporting created an all-important reciprocity between the platform and the press. The platform, in itself transient and local, was transformed into a national medium. For O'Connor the heightening of a national consciousness which such reporting helped to evoke was central to national leadership.

A medium was also provided through which local groups of Chartists could communicate with one another. Thus when O'Connor was undermining the authority of the middle-class leadership of the Birmingham Political Union at the end of 1838, the Chartists of Manchester and South Lancashire sent warnings to their Birmingham comrades through the columns of the Star. "Beware working men; do your own work, let not rich merchants lead you. [...] Take your affairs into your own hands. We have no rich men leading or driving us but, in the true democratic spirit manage our own affairs." 1 Along with O'Connor's leadership, the Star was crucial in imposing a national Chartist pattern on Birmingham radical politics. When the workingclass Chartists of Birmingham finally broke with their middle-class leaders, in the spring of 1839, the hostility of the Birmingham Journal, the organ of the middle-class radicals, meant that the Star became their only channel of protest. ${ }^{2}$ Thus the Star was the major institution for the transmission of a national Chartist unity, and for the consolidation of O'Connor's claims to leadership.

\section{V}

One of the most distinctive features of the Star was the talent and wide radical experience of its staff, who were never merely O'Connorite mouthpieces. Like Hetherington, O'Connor depended upon a gifted staff of writers. The ex-handloom-weaver Joshua Hobson, printer, publisher and later editor of the Star, from 1843 to 1845 , was a radical of long service. He had been one of the committee of working men who

system enabled reporters to take down the proceedings of meetings verbatim, Read, Press and People, p. 86.

1 Northern Star, December 22, 1838, p. 8; also December 8, pp. 1, 3, 4, for Stalybridge and Ashton addresses. The Star was quickly crowded with resolutions supporting O'Connor and Stephens against the Birmingham leaders

2 See the comments of Mrs Toll, president of the Birmingham Female Political Union, who told the female Chartists that the Birmingham Journal now "but laughs at female virtue and female politicians [...] but ladies, we have a substitute [...] in our own Northern Star (cheers)". Northern Star, July 6, 1839, p. 8. Also see the comments of the Birmingham Chartist James Taylor, ibid., August 3, p. 7. 
originally enlisted Oastler in the ten-hours campaign. Through his Voice of the West Riding he had been one of the leading figures in the provincial campaign for an unstamped press. ${ }^{1} \mathrm{He}$ was a prominent Owenite socialist, and from 1839 to 1841 published Owen's Nere Moral World. Hobson was also a founder member of the Leeds Working Men's Association. Professor J. F. C. Harrison has described Hobson as "a kind of representative bridge-figure, in that his activities spanned most of the popular radical movements of the time". ${ }^{2}$ The Star's editor, Rev. William Hill, had also been brought up as a handloom weaver in Barnsley, was an experienced radical and an able journalist. He was particularly active in the factory movement and was the Swedenborgian pastor of the New Jerusalem church at Hull. ${ }^{3}$ Until the Star moved to London in 1844 John Ardill, an ex-ironmoulder and one of the founders of the Leeds WMA, was employed as clerk and bookkeeper. ${ }^{4}$

From its earliest editions came inquiries to the Star concerning the activities of James Bronterre O'Brien. In January 1838, the Star was able to announce that "the valuable services of the glorious BRONTERRE" had been added "to the phalanx of talent already attached to the Northern Star". ${ }^{5}$ In O'Brien O'Connor had secured the services of the most talented radical journalist of the day. Although O'Brien had written for, edited and published many journals during the struggle of the unstamped press, it was as editor of the Poor Man's Guardian and for his clear class analysis that he was best known. ${ }^{6}$ When $O^{\prime} B$ Brien agreed to write a weekly letter for the Star, Oastler wrote to Stephens:

${ }^{1}$ Hobson was convicted three times between 1833 and 1836, and sent to prison twice for his role in the unstamped campaign. Collet, History of the Taxes on Knowledge, op. cit., I, p. 39; Report of the Select Committee on Newspaper Stamps, Appendix 2; Voice of the West Riding, August 10, 1833.

2 Harrison, Learning and Living, p. 98.

${ }^{3}$ Newcastle Weekly Chronicle, March 10, 1883, p. 2 ; Alexander Paterson, loc. cit.; Harrison, "Chartism in Leeds", p. 74, note 1; British Museum, Add. Mss 27820 , f. 150, for Place's predictably low opinion of Hill.

- Ultimately Ardill and O'Connor quarrelled over finances, but keeping the Star's accounts in order was no easy job. Apparently O'Connor rarely bothered to look at the accounts. Manchester Examiner, November 6, 1847.

5 Northern Star, January 27, 1838, p. 4. O'Brien was paid one guinea per column, ibid., May 10, 1845, p. 1.

- For an analysis of the importance of O'Brien and the Poor Man's Guardian, see Hollis, op. cit., ch. 7, and p. 313 for a breakdown of the papers with which O'Brien was associated during the years of the unstamped. Although a brilliant journalist, the originality of O'Brien's thought has probably been exaggerated, as Dr I. Prothero has pointed out in his review article "Chartism, early and late", in: Bulletin of the Society for the Study of Labour History, No 24 (1972), p. 52. For O'Brien in general, see A. Plummer, Bronterre: A Political Biography of Bronterre O'Brien, 1804-1864 (London, 1971). 
“Tell O'Brien to put the Poor Man's Guardian's soul into the Northern Star."1 According to the Star, "The people of England owe more to Bronterre than to any man living." 2 O'Connor dubbed him the "Chartist Schoolmaster". Place commented that O'Brien's purpose when he joined the Star was "what it always had been, the destruction of all property in private hands, all profit, all interest, all accumulation, and then to bring down the middle and upper classes and to elevate the working class to one common level". ${ }^{3}$ Certainly O'Brien brought a vigorous, defiant intellectual tone to the Star's columns. Although O'Brien discontinued his regular column in late 1838 on becoming editor of the Operative, another Chartist paper, as late as 1841-42 there are indications that O'Connor wished to employ O'Brien either as editor of the Star or of a new Chartist daily. ${ }^{4}$

O'Connor was also able to call upon the services of a number of well-established radical leaders in the role of reporters; men such as George White, ex-woolcomber, founder member of the Leeds WMA and one of the West Riding's most determined working-class militants. Through the Star talented younger men advanced. G. J. Harney and Ernest Jones, who both became leading members of the international socialist group of Fraternal Democrats and friends of Marx and Engels, were assistant editors. Harney, who had been a reporter for the Star since 1841, was editor from 1845 until 1850.5 The printer and ex-stuffweaver William Rider, active in radical politics since at least 1831 as ten-hours agitator, contributor to Hobson's Voice of the West Riding and founder member of the Leeds WMA, probably replaced Harney as editor in 1850 . Rider was closely associated with O'Connor and the Star from the paper's early days. George A. Fleming, leading Owenite, for many years editor of the New Moral World and editor of The Union, 1842-43, became assistant editor when the paper moved to London, and was to be the Star's last editor. ${ }^{6}$ Engels, at various times

1 Holyoake, Life of Stephens, op. cit., p. 86.

2 Northern Star, December 16, 1837, p. 5.

${ }^{3}$ British Museum, Add. Mss 27820, ff. 154-55.

4 Northern Star, October 13, 1838, carried O'Brien's last letter for the paper. John Watkins, John Watkins to the People, in Answer of Feargus O'Connor (London, 1844), pp. 9-12, reproduces a letter from O'Brien in which he discusses the question of O'Connor wishing to employ him in the early 1840 's. Rumours of such a move were current enough for Hill to write to O'Connor in January 1842 about O'Brien and the Star. Hill, A Scabbard, op. cit., pp. 7-8.

${ }^{5}$ Read and Glasgow, Feargus O'Connor, op. cit., p. 65, mistakenly wrote that Harney became editor in 1847. For Harney, see Schoyen, The Chartist Challenge. - For Fleming, see obituary in Manchester City News, May 25, 1878, p. 3; G. J. Holyoake, History of Co-operation (London, 1875), chs 9, 10 and 12. Along with the Star's publisher in 1852, McGowan, Fleming bought the paper from O'Connor. 
from November 1843, acted as foreign correspondent under the anonymous heading of "Our Own Correspondent". 1

Unlike many working-class radical journals, the Star paid regular and quite generous wages to its staff. As editor, Hill's salary of two pounds a week was soon doubled in 1839. For 1839-40 O'Connor stated the editorial costs of the Star amounted to fourteen pounds a week. ${ }^{2}$ Most of the unstamped papers' editors and contributors had worked gratuitously or for very little. Hetherington spent only six pounds a week for editing, reporting, reviewing, literary contributions, i.e. "making up" his stamped Dispatch. ${ }^{3}$ The Star's ability to pay regular wages was important in securing the services of such a capable journalistic team. The impression is that O'Connor was an excellent judge of talent and attracted extremely able radicals to write for his journal. He employed writers of ability and independence, not "yes" men.

Feargus wrote extensively in the Star, his main contribution being his weekly letter styled to appeal to those with "fustian jackets, blistered hands and unshorn chins", and whom he often addressed as his "political children". O'Connor wrote other leaders, helped with sections such as the Parliamentary summary and gave a column of legal advice. During the early years, when not engaged upon one of his extensive tours of agitation, O'Connor usually spent mid-week in Leeds helping prepare the paper for press. In 1843 he claimed that while Hill had been editor he had written more than Hill. ${ }^{4}$ Undoubtedly O'Connor had a capacity for prolixity. "For some time after Mr. Hobson left the paper, Mr. O'Connor so plied the office with editorial matter that there was, generally, no reason for any one to say a word", commented Harney. Eventually this situation stabilized itself, with Harney and Jones usually writing two or three articles between them, Fleming one and $\mathrm{O}^{\prime}$ Connor one or more. ${ }^{5}$

${ }^{1}$ Schoyen, op. cit., p. 131 and note 1, for periods Engels was writing for the Star. For Marx's and Engels's high opinion of the Star, Northern Star, July 25, 1846, p. 1.

2 O'Connor, A Letter to Hill, op. cit., p. 13; in Northern Star, August 26, 1848, p. 1, O'Connor again gave a breakdown of his editorial costs. Hobson had been paid $£ 6$ a week as editor, and Harney $£ 4$ as assistant editor. When Harney worked as editor of the provincial Northern Tribune in 1854 , he was paid $£ 1$ a week. Regular contributors to the Star were paid 10/- a column. Schoyen, pp. $101,236$.

${ }^{3}$ London Dispatch, September 17, 1836, p. 1, quoted by D. Thompson, "La presse de la classe ouvrière anglaise", loc. cit., pp. 18-19.

"O'Connor, A Letter to Hill, p. 14.

${ }^{5}$ Northern Star, March 10, 1849, p. 5. After Hobson's departure in October 1845 , O'Connor claimed that he was editor in all but name, ibid., November 21 , 1846, p. 1. 
O'Connor's weekly letter was the rallying call of the movement, outlining Chartist strategy, drawing attention to key events of the week, celebrating Chartist victories, denouncing the enemy without and warning of the traitors within their ranks. Punctuated with Irish anecdotes, romantic poetry and a fine sense of humour, his letters were intended to be read aloud. An able journalist, O'Connor could rise above his limitations as a writer through his emotional appeal and self-confident tone. His romance was essentially of the platform, and his articles were attempts to transform that urgency and vitality into print. Thomas Frost, himself a journalist and a good judge of style, wrote: "His [O'Connor's] style was vigorous, but coarse, being well sprinkled with expletives, often set forth in capitals, and spiced for the taste of the 'fustian jackets' of the Midlands and the North." Frost went on to note, however, that O'Connor was quite capable of modifying his tone and style in accordance with his audience. ${ }^{1}$

However, O'Connor was not the only mouthpiece or hero in the columns of the Star. ${ }^{2}$ Dr Hollis, with regard to the unstamped press, has argued that for a successful venture "What was important was to stamp the paper with the imprint of one man."3 This was not strictly true of the Star. Although O'Connor may have been the dominant personality, several other writers were able to make an impression and gain their own following. The Star was never O'Connor's paper in the way that the Political Register had been Cobbett's, or even the Poor Man's Guardian Hetherington's. It was always more the organ of a movement than that of any individual. ${ }^{4}$

\section{VI}

"The Northern Star was the principal paper", observed Ben Wilson; and Ben Brierley reflected that it was "the only newspaper that appeared to circulate anywhere". The Star was the Chartist paper. In its pages Chartists learned about the proceedings of the National Convention, found accounts of various defence funds, sent their

1 Frost, Forty Years' Recollections, op. cit., p. 181. In a letter to Marx Engels compared O'Connor's literary style favourably with that of Cobbett. K. Marx, F. Engels, Werke, Vol. 27 (Berlin, 1963), p. 99 (October 25-26, 1847).

2 For instance, John Arlom recalled reading the Star to his illiterate parents. "As soon as the paper came, my father would say, 'Come, take up the paper, and see first of all if George Julian has owt to say this week.' George Julian [Harney] was my father's high priest." Newcastle Weekly Chronicle, August 27, 1892, quoted by Schoyen, p. 125. Also, see the reminiscences of F.P. (Frank Peel?) in Newcastle Weekly Chronicle, March 17, 1883.

${ }^{3}$ Hollis, op. cit., p. 125.

4 D. Thompson, loc. cit., pp. 28-30, makes this point very well. 
nominations for the National Charter Association, enrolled in the Land Plan. O'Connor's success as a newspaper proprietor was directly related to the extent to which the Star embodied the movement. Francis Place commented that of the Chartist papers "not one excepting the Northern Star paid its expenses even at the time of the greatest excitement". 1 The success of the Star as the recognized organ of the movement left other Chartist papers a much diminished role. As an extreme example, when the NCA executive decided to start its own paper, The Executive Journal of the National Charter Association, at the end of 1841, it readily acknowledged the Star as the movement's paper. "Notwithstanding the existence of the Journal, we shall always conceive the Star to be the great organ of our party." 2 The NCA executive's paper lasted a short four weeks. ${ }^{3}$ It had no obvious role. The failure of The Executive Journal serves to underline the importance of the Star as the central organ of the Chartist movement. The newspaper of the party had pre-dated the party. But contrary to popular belief the ascendency of the Star was not gained through narrow editorial control. Its popularity was contingent upon its wide range of opinions and news, both local and national. Only in this way could the paper have become the forum of discussion for the Chartist movement and the working class.

Engels noted that the Star was "the only sheet which reports all the movements of the proletariat". "O'Connor and the editors always insisted that their paper was a "mirror", the "reflector" of the people's mind. This was central to the very concept of a "people's paper". Thus Rev. Hill wrote on the occasion of the Star's fifth anniversary in 1842: "I have ever sought to make it [the Star] rather a reflex of your minds than a medium through which to exhibit any supposed talent or intelligence of my own. This is precisely my conception of what a people's organ should be; this was what I saw to be wanting before the Star came into existence". ${ }^{5}$

The Star was never a sectarian journal. For instance, wide coverage

1 British Museum, Add. Mss 27820, f. 25. For the careers of other Chartist newspapers, see D. Thompson, loc. cit.; T. M. Kemnitz, "Chartist Newspaper Editors", in: Victorian Periodicals Newsletter, No 18 (1972), pp. 1-11; Hollis, op. cit., p. 119, has some useful comparative circulation figures.

2 Northern Star, October 9, 1841, p. 8.

${ }^{3}$ The Executive Journal of the NCA, price 1d, weekly, 8 pp., October 16 November 6,1841 . It was published by R. K. Philp from Bristol. Complete set in Place Collection, Set 56 (September-December 1841), ff. 195ff. Place noted that a circulation of only 2,000 copies would have kept the paper going.

${ }^{4} \mathrm{~F}$. Engels, The Condition of the Working-Class in England, in Marx and Engels on Britain (Moscow, 1962), p. 260.

5 Northern Star, November 19, 1842, p. 4. 
was given to Robert Owen's tours and Owenism in general. ${ }^{1}$ Always an accurate reflector of the labour movement's trends, in 1844 with the revival of the trade-union movement it changed its name to the Northern Star and National Trades Journal and moved its offices to London. ${ }^{2}$ Just as its columns were full of the anti-Poor-Law movement in 1837-38, in 1844-45 its pages carried long reports of the miners' struggle. O'Connor told Chartists:

"I invite you to keep your eye steadily fixed upon the great Trades' Movement now manifesting itself throughout the country, and I would implore you to act by all other trades as you have acted by the Colliers. Attend their meetings, swell their numbers, and give them your sympathy; but upon no accounts interpose the Charter as an obstacle to their proceedings. All labour and labourers must unite; and they will speedily discover that the Charter is the only standard under which they can successfully rally."3

This concern with the trade-union movement was not, however, new. For instance, the Star fully reported the great stonemasons' strike which lasted from October 1841 until June 1842.4 Dr I. Prothero has noted that in the 1840 's strikers were often completely dependent

I This is hardly surprising when one notes the number of Owenites on the Star's staff, Hobson and later Fleming as editors, and full-time reporters like Edmund Stallwood and T. M. Wheeler. O'Brien maintained that the Star had done much to unite radicals and Owenites, Northern Star, June 23,1838, p. 4 . In reply to an Owenite inquiry about coverage of Owen's Northern tour in 1838, the Star wrote: "The Socialists need not fear. The lectures of Mr. Owen shall have that space and notice which his station and motives entitle him to." Ibid., September 8, p. 4 ; September 15, p. 6, and September 22, for reports of the tour. Throughout the spring and summer of 1838, John Finch, a leading Owenite, wrote a regular weekly letter to the Star. Nor was this coverage of socialist activity short-lived. To take a few examples from 1840: Northern Star, May 23, carried a front-page report of the annual Owenite Congress; June 13, p. 3, a full report of the opening of the Manchester Hall of Science; September 26, 1840, p. 1, a report of an Owenite tea for James Rigby at Leeds. Throughout 1843 William Galpin wrote a long series of letters on Harmony Hall. An open dialogue existed between Chartists and Owenites throughout the period. For a wide-ranging discussion of the relationship between Owenism and Chartism, see E. Yeo, "Robert Owen and Radical Culture", in: Robert Owen, Prophet of the Poor, ed. by S. Pollard and J. Salt (London, 1971), pp. 84-115.

${ }^{2}$ See Northern Star, October 19 - November 30, 1844. O'Connor argued that London as the national capital was the proper place for the Star. He drew attention to improved communication facilities which London provided. The price of the paper was raised to $5 \mathrm{~d}$.

${ }^{3}$ Ibid., November 16, 1844 , p. 1.

4 Ibid., particularly late January - February 1842. 
on the Star for coverage and space for appeals for aid. ${ }^{1}$ Even after the miners established their own paper, The Miners' Advocate, some district committees still preferred to send their reports to the Star. ${ }^{2}$

Most historians of Chartism have accused O'Connor of undemocratic mangement of the columns of the Star, in which they claim only O'Connorite views found acceptance. Yet, as Reg Groves pointed out many years ago, "these self-same historians find most of their antiO'Connor material in this very paper". ${ }^{3}$ Indeed, one of the most striking qualities of the Star was its willingness to publish criticism of both its own policies and those of O'Connor, and the openness of its columns to all brands of Chartism. As for criticism of O'Connor, G. J. Holyoake commented: "In the Northern Star he [O'Connor] let every rival speak, and had the grand strength of indifference to what any one said against him in his own columns."4 In the autumn of 1839, the Star published a series of letters from Matthew Fletcher, member of the Convention for Bury, denouncing O'Connor in the harshest terms. ${ }^{5}$ When O'Connor and O'Brien clashed over the question of Chartist strategy for the 1841 general election, letters were published weekly from both leaders openly arguing their case. And O'Brien's tone was a good deal sharper, more denunciatory and less generous than that of O'Connor and the Star. ${ }^{6}$ In March 1849, the columns of the Star quite openly paraded the divisions between O'Connor and Harney, his editor. ${ }^{7}$ At certain points events perhaps strained the Star's more general democratic character - for instance, in the spring of 1842, over the issue of an alliance with the Complete Suffrage Union. ${ }^{8}$

1 I. Prothero, "London Chartism and the Trades", in : Economic History Review, Second Series, XXIV (1971), p. 210.

2 Challinor and Ripley, The Miners' Association, op. cit., pp. 40-41.

3 R. Groves, But We Shall Rise Again (London, 1938), p. 52.

4 G. J. Holyoake, Sixty Years of an Agitator's Life (London, 1892), I, pp. 106-07.

5 Northern Star, September 21, 1839, p. 7; October 5, p. 6; October 12, p. 1. These letters were also published in the Champion, and coincided with an all-out attack by that paper on O'Connor's leadership. W. G. Burns, also an ex-member of the Convention, was accorded similar latitude in attacking O'Connor in the summer of 1840 , ibid., June 13, p. 8 ; June 27 , p. 8 ; July 18 , p. 5 . So was Hetherington in 1841, ibid., May 8, p. 7; May 15, p. 1; June 12, p. 7. Nor are these isolated examples.

- Ibid., June 12, 1841, pp. 1, 3; June 19, pp. 5, 7; June 26, pp. 1, 4, 7-8; July 3 , pp. 1,5 ; July 10 , p. 4 .

7 Ibid., March 3-31, 1849.

8 For Chartist criticism of O'Connor's handling of the Star, see R. K. Philp, Vindication of his Political Conduct and an Exposition of the Misrepresentations of the Northern Star (Bath, 1842); J. B. O'Brien, Vindication of his Conduct at the late Birmingham Conference (Birmingham, 1842); Hill, The Rejected Letters, op. cit., and A Scabbard; John Watkins, Impeachment, op. cit.; W. Thomason, O'Connorism and Democracy Inconsistent with Each Other; Being a Statement of the Events in the Life of Feargus O'Connor (Newcastle, 1844). 
Naturally letters were sometimes refused insertion, private arguments curtailed, speeches at meetings not fully reported and leaders subjected to criticism. Although O'Connor repeatedly used the Star as a medium through which to attack other Chartist leaders, adversaries such as Hetherington, O'Brien, Hill, Thomas Cooper, John Watkins and Dr Peter M'Douall had their letters inserted in the Star, and usually proved as acrimonious in debate as O'Connor. Significantly, Chartist leaders regarded the publication of their letters in the Star not as a courtesy, but as a matter of democratic right. ${ }^{1}$ Still, conflict and accusations of unscrupulous control were inherent in a situation in which the movement's principal paper and most influential policymaking institution was in the hands of Chartism's most prominent leader.

If O'Connor's frequent claim that he gave the editor of the Star a completely free hand was an exaggeration, the view that the Star was an organ conceived and directed solely towards his own glory is also false. While editor, Rev. Hill was always ready to point out the freedom and editorial control which he exercised. ${ }^{2}$ Nor did Hill show any deference to O'Connor's position when he disagreed with his political opinions. For instance, O'Connor's famous denunciation of "Church Chartism, Teetotal Chartism, Knowledge Chartism and Household Suffrage Chartism" was accompanied by an editorial by Hill in which he defended Christian Chartism and suggested that O'Connor had "misconceived the whole matter." 3 G. J. Harney testified to the freedom $\mathrm{O}^{\prime}$ Connor allowed his editors. He wrote to Engels in 1846: "I must do O'C[onnor] the justice to say that he never interferes with what I write in the paper nor does he know what I write until he sees the paper."4

Hill's dismissal in the summer of 1843 was not over the question of editorial control as such or general management of the paper - although O'Connor had been unhappy about the manner in which Hill ran the

1 Thus O'Brien wrote: "I therefore demand the publication of this [letter]. I demand it, not as a favour [...] but as a matter of right". Northern Star, April 23,1842 , p. 5.

2 For instance, Northern Star, May 30, 1840, p. 4.

3 Ibid., April 3, 1841. Despite O'Connor's view that both temperance Chartism and Christian Chartism were tendencies detrimental to the need for Chartist unity, they received publicity in the columns of the Star. It is also mistaken to believe that $O^{\prime}$ Connor was opposed to teetotalism as such. For a clear exposition of O'Connor's position on drink, see B. Harrison, "Teetotal Chartism", in: History, LVIII (1973), pp. 193-217.

4 The Harney Papers, ed. by F. G. and R. M. Black (Assen, 1969), p. 241; also see pp. 251-52. 
Star for some years. ${ }^{1}$ Deep and irreconcilable differences had developed between Hill and O'Connor over important questions of NCA organization and leadership. ${ }^{2}$ Similarly the point at issue between O'Connor and Harney, over the attitude to be taken towards foreign affairs, reflected fundamental differences over the commitment of the movement to international socialism. ${ }^{3}$ But as far as exercising a dictatorial control of the paper, the Star became the organ of the Fraternal Democrats and one of the world's leading international socialist journals, with little commitment on O'Connor's part to international socialism. Despite ideological differences and serious clashes of personal ambition, Harney remained editor until August $1850 .{ }^{4}$ As Dorothy Thompson has argued, between 1845 and 1849 the "two apparently incompatible lines of action - spade husbandry and international communism - co-existed in the columns of the Star". ${ }^{5}$ Certainly Gammage's assertion that "Every paid servant of O'Connor's [...] felt himself bound to follow in the wake of his master"6 must be seriously modified.

Both O'Connor and the Star assumed a cordial attitude towards other Chartist papers, demonstrating a sense of co-operation rather than competition. Almost invariably the Star gave publicity and

1 O'Connor's dissatisfaction with Hill's general editorial style went back to 1839. F. O'Connor, Reply to Mr. Hill's "Scabbard" (London, 1843), pp. 2, 4. HO 20/10, details of an interview with O'Connor while in prison in 1841: “ $\mathrm{He}$ [O'Connor] complains greatly of the present Editor, Hill, and his injudicious mode of conducting it [the Northern Star]."

${ }^{2}$ Hill issued a series of severe censures upon the NCA executive in late 1842 and early 1843. Eventually O'Connor felt it necessary to intervene to declare that Hill's opinions did not represent his own. Hill in his reply to O'Connor's letter corroborated O'Connor's statement that he "has been no party to any syllable that I have written upon the conduct of the Executive". Northern Star, February 4, 1843, pp. 1, 5. The issue blew up again in summer of 1843 with Hill's denunciation of Dr M'Douall, and O'Connor dismissed him as editor. Ibid., July 8, p. 4; July 15, p. 4; August 12, p. 4.

${ }^{3} \mathrm{O}^{\prime}$ Connor did not reject the need for foreign news as such, nor was he totally hostile towards the Fraternal Democrats. See The Harney Papers, op. cit., letters 79 and $80 ; \mathrm{H}$. Weisser, "Chartist Internationalism, 1845-48", in: Historical Journal, XIV (1971); id., "The Role of Feargus O'Connor in Chartist Internationalism", in: The Rocky Mountain Social Science Journal, VI (1969).

"See Weisser, "Chartist Internationalism", pp. 55-56; Schoyen, p. 131, notes "the considerable truth in his [O'Conner's] boast that his editors were given a free hand". O'Connor seems to have sincerely regretted losing Harney's services when he finally did resign, see his letter to Harney of August 20, 1850, The Harney Papers, p. 64.

D. Thompson, loc cit., pp. 28-29.

- Gammage, op. cit., p. 200. 
support to new Chartist journals. ' O'Connor contributed to help O'Brien keep the Operative alive and later acted as surety for O'Brien and Carpenter's Southern Star. The Star publicized the campaign for the O'Brien press fund in 1841-42, despite the mounting bad feeling between O'Brien and O'Connor. ' O'Brien's newspaper projects were not the only ones to which O'Connor offered his help. In 1842 he wrote a long series of articles on the land for the struggling English Chartist Circular in an attempt to boost its sales. ${ }^{3}$ Feargus sent a donation to the Leicester Chartists to help start the Midlands Counties Illuminator, and in 1842 wrote a series of letters to Cooper's The Commonwealthsman. ${ }^{4}$ While the Star remained the organ of the Chartist party, O'Connor always felt the movement needed a far wider range of journals. This was a general Chartist concern. ${ }^{5}$ Although the Chartist movement gave birth to a wide range of journals, some of which lasted several years, there was no flourishing of working-class papers comparable to the years of the unstamped press. Instead Chartism brought forth a new type of working-class journal. The Star represented a new departure in the history of the working class, in terms of the concentration of the entire strength and variety of a mass movement of working-class protest into the columns of a single national newspaper.

${ }^{1}$ For instance, contrast the Star's attitude to the proposed new Charter newspaper with that of both the Operative, November 4, 1838, p. 1; November 18, pp. 40-41; December 2, p 72, and the London Dispatch, October 14, p. 868. The Star, November 10, 1838, p. 4, weicomed the Operative, the True Scotsman and the Charter, the organ of the London Working Men's Association, with enthusiasm: "A good cause can never have too many champions. There is room enough for the labour of all [...] in [...] helping forward the glorious consummation of our hopes." In 1841 the Star referred to the National Vindicator, the journal of Vincent and Philp (hardly O'Connor's closest allies), as "the ablest fellow-worker in the cause of Chartism", September 18, p. 4.

2 O'Connor, A Letter to Hill, p. 28; Northern Star, September 28, 1839, p. 4; December 28, p. 5; January 11, 1842, p. 4; July 9; Southern Star, January 26, 1840 , p. 5 ; Plummer, Bronterre, op. cit., pp. 140, 164-65. Carpenter and O'Brien had trouble for several months arranging sureties with the Stamp Office, which had turned down both Joshua Hobson and Harriet West. O'Connor and Alderman Scales eventually were accepted.

${ }^{3}$ In the English Chartist Circular, No 57 (1842), O'Connor gave his reasons for offering his services gratuitously to the paper.

4 John Seal to Place, Leicester, July 15, 1841, British Museum, Add. Mss 27835 , ff. 165-68: O’Connor gave $£ 7$ and Duncombe later gave $£ 10$ for the Illuminator. For Cooper's later paper, The Commonwealthsman: or, Chartist Advocate, two copies exist in $\mathrm{HO} 45 / 260$, of which No 20 , June 18,1842 , carries the third of a series of letters from $\mathrm{O}^{\prime} \mathrm{Connor}$.

${ }^{5}$ See, e.g., the letter of James Harris, editor of the English Chartist Circular, on the demise of the paper, in No 153 (1843). 


\section{VII}

Almost as soon as the Star was showing a profit, O'Connor was planning a more ambitious scheme: a daily London paper. ${ }^{1} \mathrm{He}$ asserted that the establishment of a daily journal was essential for the marshalling of public opinion. "Public opinion" was a key political concept of the period. This was reflected in the Chartist strategy for the obtainment of the six points, which emphasized the necessity of open agitation and organization in order to create an overwhelming public opinion, as in 1831-32, which government could neither ignore nor suppress. The Star thus explained the value of the press to the people's party:

"If the people were unanimous upon any measure, but it suited not the press to convey that unanimity, the identity of opinion would be useless. The great value of the Press to its party, then, is that it serves as a herald to proclaim to all the united opinion of all, and under its banners the forces are mustered without the expenditure of much time or money."'2

O'Connor was not alone in arguing the movement's need for a daily press. Support was forthcoming from O'Brien, Harney and the members of the London Democratic Association, and various groups of West Riding radicals. ${ }^{3}$

Probably lack of funds combined with the tremendous demands being made upon his energies forced $O^{\prime}$ Connor temporarily to shelve these early plans for a daily paper. ${ }^{4}$ Almost certainly 1839 was the only point at which such a paper would have been a real possibility. However, when discussions were opened upon the question of the re-organization of the movement in the summer of 1840 , O'Connor outlined a plan of organization based upon a daily newspaper, the profits of which were to finance lecturers, delegates to Conventions, defence funds and Chartist agitation in general. ${ }^{5}$ No doubt wisely the

1 Northern Star, March 17, 1838, p. 4, announced the establishment of the Evening Star, to be published from London from November 1, and to involve Hill, O'Brien and O'Connor.

2 Ibid., June 23, 1838, p. 6.

3 Ibid.; also July 14, p. 4; December 8, p. 5 .

${ }^{4} O^{\prime}$ Connor was still proposing to bring out a daily paper at a meeting of the St Pancras WMA, ibid., December 22, p. 8. Perhaps O'Connor was put off the idea by his comrades. In August 1838, Oastler wrote to Stephens: "O'Connor promised me that until the Star was clear and independent, he would not meddle with a daily paper." Holyoake, Life of Stephens, p. 85.

5 Northern Star, July 18, 1840, p. 6. As soon as O'Connor came out of prison in late 1841 , he was again campaigning for a daily paper, ibid., October 9,1841 , p. 1. 
founding conference of the NCA did not act upon this proposal. But what $\mathrm{O}^{\prime}$ Connor clearly demonstrated was that his conception of the role of the newspaper went well beyond that of mere propagandist and educator. In 1838 the Star had argued: "The press is at once the cheapest, the most expeditious, and the most certain means of keeping a party together." 1 The organization of the movement centred around a national paper. O'Connor always sought to impart the utmost permanency to the movement's national organization and he believed, however mistakenly, that a national Chartist daily paper provided a key to this problem. When he finally did take over the Evening Star as a Chartist daily, in the role of manager and editor, during the summer of 1842, it proved a grave disappointment. Chartism's first and only daily paper lasted only half a year and lost a large sum of money. ${ }^{2}$ There were many reasons for the Evening Star's failure, not least of all that working men and women could not afford 3d and then

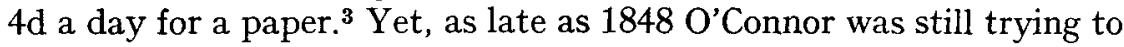
establish a Chartist daily to be called The Democrat. ${ }^{4}$

Without a daily Chartist press the Star assumed the role of national organizer. Besides providing the Star with news, the full-time reporters also served as organizers for the Chartist movement. In 1841 Harney became the Star's Sheffield correspondent, T. M. Wheeler took on the job of London reporter and agent, and George White was given the difficult task of organizing the O'Connorite-NCA party in Birmingham and reporting for the Star. ${ }^{5}$ As the Star's Birmingham reporter White earned one pound a week. ${ }^{6}$ Thus the Star helped to fulfil the movement's

${ }^{1}$ Ibid., June 23, 1838, p. 6.

2 O'Connor was editor of the Evening Star from August 23, 1842, until February 1, 1843; G. F. Pardon was the publisher. Due to heavy losses the price of the Evening Star was raised from $3 d$ to $4 d$ a copy, Evening Star, September 19, p. 2. According to O'Connor the paper lost $£ 3500$ supporting Chartist principles, ibid., February 1.

${ }^{3}$ O'Connor told Chartists: "I do not ask you, already too poor, to buy this Paper, but I do ask you to push it into every resort of the Working Classes." Evening Star, August 23, p. 2.

4 Northern Star, May 13, 1848, p. 4 ; Gammage, op. cit., p. 328.

- Schoyen, p. 105; Northern Star, October 9, 1841, p. 7; January 30, p. 5 Wheeler, like so many of the Star's staff, had been connected with the Owenite movement. He was secretary of the Kensington socialists. New Moral World, November 16, 1839, p. 893. For Wheeler, see William Stevens, A Memoir of Thomas Martin Wheeler (London, 1862); obituary in Reynold's Weekly Newspaper, June 8, 1862. From 1839 to 1841, R. E. Lee, prominent figure in the unstamped as editor of The Man, was the Star's London correspondent. From 1843 Edmund Stallwcod, also a veteran of the unstamped, was O'Connor's London reporter, until August 1850, after which Wheeler again took the job.

${ }^{6}$ Northern Star, April 24, 1841, p. 7. 
organizational requirements by providing working-class Chartist leaders with the necessary financial independence to undertake fulltime agitation, to become in effect "professional revolutionaries". O'Connor not only owned the major medium of Chartist communication, his correspondents formed a political machine. The reporters and staff of the Star were frequently denounced as "O'Connor's tools". At the 1842 Convention O'Connor defended himself against such accusations.

"It had been stated, that his reporters were hired tools, while the reporters of other papers were public spirited individuals. $\mathrm{He}$ could positively assert that he never wrote a line to Wheeler in his life, that he never wrote a line to White, or any of his correspondents; he had been particularly careful on this point $[\ldots]$ they had been entirely free and unshackled from any restraint [...]. The Editor of the paper he had known for many years, and had never written a line to him to influence his conduct $[\ldots]$. Great latitude must always be allowed to a public newspaper". ${ }^{1}$

And George White denied that O'Connor or any man could buy his services at the cost of his principles.

"With regard to the agents of the Northern Star being the paid tools of Feargus O'Connor, as one of those agents, he could assert, that he was in the same position for doing his duty fearlessly as before he accepted that office; his actions were equally free as before. It was well known that when he was employed in Yorkshire, he would never be controlled in his opinions or his actions by his employer, and should act now in a similar manner. So far as O'Connor supported the cause he would support him, whether he was called a tool or not; and if he ( $\mathrm{O}^{\prime}$ Connor) deserted the cause, he would be one of the first to oppose him."2

O'Connor insisted that anyone accepting employment in the NCA organization could not also work for the Star, in order to ensure their

1 Ibid., April 30, 1842, p. 6.

2 Ibid. For accusations that the Star's reporters were just O'Connorite "tools", see John Jackson, The Demagogue Done Up (Bradford, 1844); John Humffreys Parry, A Letter to Feargus O'Connor, Farmer and Barrister (London, 1843). According to Parry only "the Whites, the Wheelers, the Harneys, and the Stallwoods of this world" supported O'Connor, p. 11. This pamphlet brought indignant replies from both O'Connor and White. F. O'Connor, A Letter from Feargus O'Connor, Esq., to John Humffreys Parry, Barrister at Law; But neither Farmer nor Lawyer (London, 1843); G. White, An Answer to John Humffreys Parry, of the Middle Temple, Barrister at Law; and An Exposure of the Self-Styled Liberals and Free Traders (London, 1843). 
independence. Thus O'Connor informed T. M. Wheeler that if he accepted the post as Secretary to the NCA executive, he could no longer be employed by the Star. Edmund Stallwood, the West London socialist and Chartist, replaced Wheeler as the Star's London correspondent. ${ }^{1}$

Not only did the Star support the activities of some of the movement's most capable agitators, its profits went to provide financial assistance for many Chartist prisoners and their families. For instance, a week's profits went to Frost's defence. ${ }^{2} \mathrm{O}^{\prime}$ Connor even suggested financing another Convention out of the Star's profits after the National Convention was dissolved in September 1839. ${ }^{3}$ The Star's staff were well paid and the profits after 1839 fell off greatly. There was probably much truth in O'Connor's claim that he spent every penny of the Star's profits on agitation and a good deal of his own wealth on the cause. ${ }^{4}$ What O'Connor gained through his ownership and earnings of the Star was his total independence as an agitator in the people's cause, a factor of incalculable importance to his leadership. The crucial issues concerning the finances of the Star relate not to quibbles over how much initial capital O'Connor could or would advance, but to key questions of Chartist organization and leadership. The importance of the Star's profits was not as a brilliant stroke of financial speculation, but rather as a contribution to the creation of regular and permanent national Chartist organization, along with the freedom such funds allowed the movement's most gifted agitator to constantly tour the country propagandizing, winning new recruits and organizing. O'Connor

1 Northern Star, September 16, 1843, p. 6; Stevens, A Memoir of Wheeler, op. cit., p. 24.

2 Northern Star, December 7, 1839, p. 4. O'Connor also gave $£ 20$ a year from the Star's profits to Mrs Frost, ibid., May 22, 1841, p. 5; an initial contribution from the Star to the Stephens Defence Fund was £50, February 9, 1839, p. 4; O'Connor opened the National Defence Fund with a contribution of $£ 20$, June 15,1839 , p. 4 ; in just over six months, while in prison, O'Connor gave $£ 110$ to the Victims Fund, December 19, 1840, p. 5. While O'Brien was in prison the Star paid his family one pound a week, totalling $£ 80$, Plummer, Bronterre, $p$. 153; also see O'Connor to Allsop, April 26 [1840], Allsop Collection, British Library of Political and Economic Science, University of London. Privately O'Connor complained of the great financial burden of affording such massive relief to families of victims, HO 20/10. Although we have no comprehensive breakdown of the expenditure of the Star's profits, the examples cited above and other such examples suggest that Government prosecution placed considerable strain on these profits.

3 Northern Star, September 21, 1839, p. 3.

4 See ibid., October 5, 1839, p. 4; July 18,1840 , p. 6; January 30 , 1841, p. 7 ; June 24, 1843, p. 1 ; November 23, 1844, p. 1 ; August 26, 1848, p. 1 ; and Schoyen, p. 133, note 1 . 
did not become a rich man from the profits of the Star. He became the undisputed leader and champion of Chartism.

However, the question of the role of reporters and profits of the Star in Chartist organization highlights the basic contradiction at the centre of O'Connor's relationship to the paper. While the Star was the organ of a democratic movement and the Chartist party, the NCA, it was owned by O'Connor. There was no clear line between O'Connor's private business concern and the finances of the movement. While O'Connor's leadership was very closely linked to both the Star and the $\mathrm{NCA}$, in a sense it remained above them both. When the profits of the Star were placed at the disposal of the movement, this was regarded as an act of largesse on the part of O'Connor. This related to an older tradition of gentlemanly leadership. His claim that "The Star is mine and the People's, and only ours" 1 embodies the essence of the style of leadership associated with the "People's Champion", in which the relationship between leadership and led, Champion and people, is direct and unmediated. As the Star's success was dependent on the wide support of the working class, there was always an appeal to a vague brand of popular democratic control. From the platform at Bolton, Feargus solicited the working class for a mandate to continue in the role of journalist, a task he had undertaken "according to the terms of a contract which had been mutually entered into between him and the people; and now he came to ask them whether or not that contract was to be renewed for one year more. (Repeated cheers, and 'aye, aye'.) Then he would proceed, fearless of all consequences, when backed by the brave working classes."

The establishment of a national newspaper was a vital prerequisite to the emergence of the Chartist party. Through the Star's columns the Chartist movement was brought together and held together for over a decade. The Star played an essential role in keeping Chartism alive during the most difficult times of government repression. George White maintained that the Star "had been the main cause for keeping the agitation alive when there were many of them in prison, and when all their prospects were dark and gloomy. When he was in prison, he recollected being asked by thirty or forty in the court yard what would become of the cause? He asserted that the Northern Star would keep them together. It had done this; and the people owed to it a debt of gratitude." 3

1 Northern Star, January 18, 1845, p. 4.

2 Ibid., November 3, 1838, p. 8 ; also see editorial on first anniversary, November 17, p. 4.

3 Ibid., April 30, 1842, p. 6. 
Throughout the 1840's the Northern Star, the National Charter Association and the "People's Champion" captured the allegiance of thousands of working people, as the three central institutions of national Chartist unity. Many Chartists regarded the establishment of the Star as O'Connor's greatest contribution to the cause of popular rights. As a local Chartist from Hull told a meeting,

"If it had not been for the protection which the Northern Star afforded, they would still be as slaves in the desert, and their own sounds might echo through the wilderness, but O'Connor threw them with all the force and power of union into the enemies' camp. [...] In all ages, we have found that the most difficult object of accomplishment, has been the marshalling of public opinion, and the Star has done more to effect that object than ever has been done." 1

O'Connor himself was in no doubt as to the Star's place in the history of the British working class. "The first paper ever established in England exclusively for the people; a paper which has given a completely new tone to the whole press of the empire; a paper which may be truly called the mental link which binds the industrious classes together; a paper which has, for the first time, concentrated the national mind into one body." 2

\section{APPENDIX}

\section{Circulation History of the Northern Star}

The yearly circulation figures of the Star are easily come by, through the Stamp Returns. ${ }^{3}$ Not surprisingly, the figures correlate generally with the degree of Chartist activity at any given time. Within given years the figures may fluctuate with events. Thus, in April 1848 O'Connor claimed the April 15 edition sold 21,000, almost 10,000 more than the yearly weekly average. ${ }^{4}$

1 Ibid., August 18,1838, p. 3; also see address of the Dewsbury Chartists to O'Connor, ibid., December 11, 1841, p. 7.

2 Ibid., January 16, 1841, p. 7.

3 Annual stamp returns were published in Parliamentary Accounts and Papers. They are also conveniently listed in the Report of the Select Committee on Newspaper Stamps, Appendix 4.

4 Northern Star, August 26, 1848, p. 1. 
Yearly Average Weekly Sales of the Northern Star, calculated from number of stamps bought per year

$\begin{array}{rrrrrr}1838 & 11,000 & 1842 & 12,500 & 1847 & 8,700 \\ 1839 & 36,000 & 1843 & 8,700 & 1848 & 12,000 \\ 1840 & 18,700 & 1844 & 7,400 & 1849 & 7,000 \\ 1841 & 13,500 & 1845 & 6,500 & 1850 & 5,000\end{array}$

From the extremely low amount paid in advertising duty by the Star, it is clear that the paper was almost entirely dependent upon its wide sales for support. ${ }^{1}$

1 Advertising duty can also be discovered through Accounts and Papers up until 1843. Most provincial papers with half the Star's circulation had many times its advertising revenue. O'Connor often claimed that he refused advertisements in order to keep space open for politics. 